NBER WORKING PAPER SERIES

\title{
POLITICAL BUDGET CYCLES IN NEW VERSUS ESTABLISHED DEMOCRACIES
}

\author{
Adi Brender \\ Allan Drazen \\ Working Paper 10539 \\ http://www.nber.org/papers/w10539

\section{NATIONAL BUREAU OF ECONOMIC RESEARCH 1050 Massachusetts Avenue Cambridge, MA 02138} \\ June 2004
}

\begin{abstract}
We wish to thank Amir Marchak and Sagie Dagan for superb research assistance. We have benefited from the comments of Alessandra Casella, Marcela Eslava, Zvi Hercowitz, Nuno Limão, Daniele Paserman, Ken Rogoff, Rob Sauer, Jakob Svensson, and seminar participants at the Bank of Israel, the 2003 International Seminar on Macroeconomics, the University of Maryland, University of Pennsylvania, New York University, and the Hebrew University of Jerusalem. The second author wishes to thank the Jack and Lisa Yael Chair in Comparative Economics, Tel Aviv University for financial support and the Research Department of the Bank of Israel for its hospitality. The views expressed in the paper do not necessarily reflect those of the Bank of Israel. The views expressed herein are those of the author(s) and not necessarily those of the National Bureau of Economic Research.
\end{abstract}

(C)2004 by Adi Brender and Allan Drazen.. All rights reserved. Short sections of text, not to exceed two paragraphs, may be quoted without explicit permission provided that full credit, including $(\subset$ notice, is given to the source. 
Political Budget Cycles in New versus Established Democracies

Adi Brender and Allan Drazen

NBER Working Paper No. 10538

June 2004

JEL No. D72, E62, D78

\title{
$\underline{\text { ABSTRACT }}$
}

Like other recent studies, we find the existence of a political deficit cycle in a large cross-section of countries. However, we find that this result is driven by the experience of "new democracies". The strong budget cycle in those countries accounts for the finding of a budget cycle in larger samples that include these countries; when these countries are removed from the larger sample, so that only "established" democracies remain, the political budget cycle disappears. The political deficit cycle in new democracies accounts for findings in both developed and less developed economies, for the finding that the cycle is stronger in weaker democracies, and for differences in the political cycle across governmental and electoral systems. Our findings may reconcile two contradictory views of pre-electoral manipulation, one arguing it is a useful instrument to gain voter support and a widespread empirical phenomenon, the other arguing that voters punish rather than reward fiscal manipulation.

Adi Brender

Research Department

Bank of Israel

Jerusalem 91007

Israel

adib@bankisrael.gov.il

\author{
Allan Drazen \\ Berglas School of Economics \\ Tel Aviv University \\ Ramat Aviv 69978 \\ Israel \\ and NBER \\ drazen@post.tau.ac.il
}




\section{Introduction}

A common perception is that incumbents often try to use expansionary economic policy before elections to increase their re-election chances. Most politicians and nonpoliticians alike would probably subscribe to this view, and the term "election-year economics" or its equivalent is common in many countries. ${ }^{1}$

In the political economy literature, this view is summarized as the "political business cycle", that is, the possibility of a macroeconomic cycle induced by the political cycle. Models of the political business cycle are motivated by the finding that good macroeconomic conditions prior to the elections help an incumbent to get re-elected, a finding that has wide support in studies (conducted mainly in developed economies). ${ }^{2}$ The strength of this finding was an important factor generating formal modeling of how opportunistic incumbents may manipulate economic policy to induce economic expansions before elections.

However, notwithstanding both common perceptions and the substantial evidence that a "strong economy" helps incumbents get re-elected, empirical studies - especially in developed economies - provide little evidence of a regular and statistically significant increase in economic activity before elections. ${ }^{3}$ In short, voters care about the economy but this does not appear to translate into econometrically verifiable cycles in aggregate economic activity.

Given the lack of empirical evidence for political cycles in economic outcomes, a literature examining possible cycles in policy instruments has developed. More

\footnotetext{
${ }^{1}$ Tufte (1978, p.3) begins his famous book on the political business cycle with a quote from 1814 , "A Government is not supported a hundredth part so much by the constant, uniform, quiet prosperity of the country as by those damned spurts which Pitt ]used to have just in the nick of time."

${ }^{2}$ The most influential work is probably that of Fair $(1978,1982,1988)$, who found such results for the U.S. In his original article, Fair looked at presidential elections from 1916 through 1976, and found that the change in real economic activity in the year of the election appears to have an important effect on votes for president. Specifically, a one percent increase in the growth rate increases the incumbent's vote total by about one percent. Numerous other articles find similar results on the importance of pre-election conditions on voting patterns in both the U.S. and other countries. Looking at voting or popularity functions, Lewis-Beck (1988) found that the sort of results that Fair reports for the U.S. hold in Britain, France, West Germany, Italy and Spain as well. Madsen (1980) reported similar results for Denmark, Norway, and Sweden.

${ }^{3}$ See Drazen (2000), chapter 7, for a review of the empirical evidence on opportunistic political business cycles in economic activity.
} 
specifically, the focus is on fiscal expansions in election years meant to generate the desired electoral effects, termed the "political budget cycle". Conventional wisdom, supported by the findings of a number of econometric studies using large cross-country data sets, is that the political budget cycle is a widespread phenomenon, a result that we find as well. (We discuss these papers in greater detail in section 3 below).

A very different view casts doubt on the widespread existence of political cycles in macroeconomic policy. While it is agreed that a "strong economy" helps incumbent's re-election prospects, it is argued that politicians have very limited ability to successfully manipulate the economy to help their re-election chances. There are at least two reasons to question whether politicians will engage in pre-electoral monetary and fiscal expansion in order to manipulate aggregate economic activity. First, there is the technical question of whether it is possible to time the expansion accurately enough to happen just before the elections. Though high precision missiles may now dominate military conflict, the economic equivalent in electoral conflict is believed not to exist. It is impossible to finetune the aggregate economic effects of economic policy so that they can be turned on and off with sufficient precision. ${ }^{4}$

Even if it were technically possible to time precisely the aggregate effects of policy, manipulating economic activity is considered harmful to the economy over time in terms of "unsmoothing" consumption, inducing investment cycles, etc. If voters are rational and well informed they would not support such policies, so that pre-electoral manipulation would be punished rather than rewarded at the polls. This is argued in a number of papers, such as Peltzman (1992), Alesina, Perotti and Tavares (1998), and Brender (2003), which present evidence that voters in developed economies are "fiscal conservatives" and often tend to remove deficit-producing incumbents from office.

The lack of an aggregate fiscal cycle, and particularly avoiding deficits before elections, does not mean that incumbents do not use fiscal policy to influence voting. Fiscal manipulation may occur at a level other than the aggregate, for example, transfers to one group offset by a reduction in transfers to other groups of voters or in changes in the composition of spending towards spending valued by "impressionable" voters. This would allow fiscal manipulation to work, but would be consistent with voters being fiscal

\footnotetext{
${ }^{4}$ See, for example, Lewis-Beck (1988).
} 
conservatives who dislike the need to finance higher aggregate spending. Provided that the overall budgetary change is small enough, it would also be consistent with it being harder to detect fiscal manipulation.

In this paper we find a political budget cycle in a large cross-section of countries, but argue that this finding is driven by the experience of "new democracies", where fiscal manipulation may work because voters are inexperienced with electoral politics or may simply lack the information needed to evaluate fiscal manipulation that is produced in more established democracies. It is the strong fiscal cycle in these countries that accounts for the finding of a fiscal cycle in larger samples including these countries. Once these countries are removed from the larger sample, the political fiscal cycle disappears. The political cycle in new democracies accounts for findings in both developed and less developed economies, for the finding that the cycle is stronger in weaker democracies, and for differences in the political cycle across government or electoral systems.

Our findings also reconcile the two contradictory views of pre-electoral manipulation set out above: one that it is reasonable to expect politicians to engage in such manipulation and that empirically it is widespread; the other, that voters punish rather than reward fiscal manipulation. In new democracies it is possible to carry out such manipulation, whereas in more established democracies, voters have the ability to identify fiscal manipulation and punish such behavior, so that politicians avoid it.

The plan of the paper is as follows. In the next section we summarize the existing evidence for a political budget cycle. This includes earlier evidence for the political fiscal cycle, mostly from less-developed countries, as well as more recent papers arguing that a cycle is observed in both less-developed and developed countries. In section 3, we set up the basic empirical work, discuss a number of data and estimation issues, and present the basic regressions for the set of democracies as a whole. In section 4 , the heart of the paper, we demonstrate that the political budget cycle found in larger data sets is due to the significant political cycle in "new democracies". In section 5, we consider some arguments on observable characteristics of countries that may account for the cycle and argue that these too are new democracy effects. In section 6 , we discuss 
conceptually why the political budget cycle is a phenomenon of "new democracies". Section 7 concludes. A Data Appendix contains a detailed description of the data.

\section{Evidence on Fiscal Cycles - A Summary}

For less-developed countries, there are a large number of both country and crosscountry studies that point to the existence of a political budget cycle. Ames (1987) presents a panel study of 17 Latin American countries in which he shows that over the period 1947-1982, government expenditures increased by $6.3 \%$ in the pre-election year and decreased by $7.6 \%$ in the year after the election. Block (2000) presents evidence of a political business cycle in both fiscal and monetary policy in a cross-section of 44 SubSaharan African countries. Schuknecht (1996) is a comprehensive study of the political business cycle in 35 less-developed countries over the period 1970-92. ${ }^{5}$ He argues that there is more room for manipulation in LDCs, as checks and balances are weaker and the incumbent has more power over monetary and fiscal policy. He suggests that in LDCs, expenditure policies, such as distribution of free or subsidized goods or employment generation via public works programs, are probably more effective than tax cuts to affect voter behavior. He finds a clear significant effect of elections on the fiscal balance, but no significant effect on output. Individual country studies arguing for a significant political fiscal cycle include Ben-Porath (1975) for Israel over the period 1952-73, Krueger and Turan (1993) for Turkey over the period 1950-1980, and Gonzàlez (2002) for Mexico over the period 1958-1997, to name a few. Drazen (2001) presents further discussion.

For developed countries, fiscal manipulation observable at the aggregate level is thought to be less common. Individual country studies generally do not find a regular, statistically significant political budget cycle. Alesina, Roubini, and Cohen (1997) find a budget balance cycle in a set of 13 OECD economies over the period 1960-1993 (about half of the countries have observations only from 1970 onward), but no significant cycle in the components of the budget. In the United States, Keech and Pak (1989) found a cycle for veteran benefits in the United States between 1961 and 1978. Consistent with the findings of Keech and Pak, Alesina, Cohen, and Roubini (1992) find evidence of a

\footnotetext{
${ }^{5}$ See also Block (2002) for a recent cross-section study.
} 
political cycle in transfers relative to GNP in the U.S. over 1961 to 1985 , which they argue disappears if one extends the sample either forward or backward. They find no statistically significant political cycle in other fiscal instruments. ${ }^{6}$

Two recent studies find evidence that the political budget cycle is present in both developed and less-developed countries. Shi and Svensson (2002a, 2002b) consider a panel data set of 91 countries, both democracies and non-democracies, over the period 1975-95. They find that, in an election year, the government surplus falls significantly in both less-developed and developed countries, though they show that the effect is far stronger in less-developed countries, consistent with earlier studies. Both government spending rises and revenues fall, though the significance differs across the data sets and the estimation technique. The economic effect is significant for the sample as a whole, the fiscal surplus falling on average in their full sample by $1 / 2$ to 1 percent in an election year, depending on the estimation method they use.

Persson and Tabellini (2002, see also Persson and Tabellini [2003, chapter 8]) argue that there is a strong political budget cycle in developed economies as well. They restrict the sample to countries with democratic political institutions and competitive elections and consider a group of sixty democracies from 1960 to 1998 . They find a political revenue cycle (government revenues as a percent of GDP decrease before elections), but no political cycle in expenditures, transfers, or the overall budget balance across countries or political systems.

\section{Estimating Political Budget Cycles in Democracies}

As is well known, the IFS data on which many studies are based are noisy. Therefore, as a first step in our empirical work, the data were "cleaned". In Table A1 in the Appendix, we set out what are the problems with the data on a country-by-country basis, and what were the adjustments that we made. (The data are available at http://www.tau.ac.il/ drazen.) On this basis, we then estimate equations similar to those estimated by Persson and Tabellini, using the same economic controls, variable

\footnotetext{
${ }^{6}$ Analyzing U.S. elections for President, Senators, and state governors in the period 1950-1988, Peltzman (1992) goes further and argues that voters penalize growth in federal and state spending at the polls. In U.S. state governor's elections, increases in spending on welfare payments are especially heavily punished, as is spending just prior to an election.
} 
definitions, and a somewhat extended sample. Our main conclusion is that in a broad cross-section of democracies over the period 1960-2001 there indeed exists a political cycle in the fiscal balance, though the strength of the cycle is sensitive to the set of countries included. In section 4 we will refine this further, and show that the crucial country characteristic is whether the country is a "new" or an established democracy.

Our basic data set consists of 106 countries for which we collect data on the central government balance, total expenditure and total revenue and grants from the IFS database. (Further details are given in the Data Appendix and Tables A1 and A2.) The sample period is 1960-2001, although the data for many countries cover shorter periods.

Our initial sample includes many countries that are not democracies. In our view, if the political budget cycle reflects the manipulation of fiscal policy to improve an incumbent's re-election chances, then it only makes sense in countries in which elections are competitive. If elections are not competitive, then the basic argument underlying the existence of a political budget cycle loses much of its validity. ${ }^{7}$ In fact, one might argue that finding a political budget cycle in non-democratic countries weakens the support for the theory, rather than strengthening it. Hence, from either an empirical or conceptual perspective, one needs to separate democratic from non-democratic countries. ${ }^{8}$

We therefore separate democracies from non-democracies, analogous to Persson and Tabellini, by applying to these data a filter for the level of democracy in each country in each year. This filter is taken from the POLITY IV project, conducted at the University of Maryland, covering nations with a population exceeding half a million people. Each country is assigned in this dataset a value that ranges from -10 (autocracy) to 10 (the highest level of democracy). We restrict our sample to democracies, by selecting only the countries that receive a score between 0 and 10 on this scale; this reduces our sample to 68 countries. These countries may be classified as those that were in the OECD for the entire sample period, the "transition" economies of Eastern Europe

\footnotetext{
${ }^{7}$ Shi and Svensson argue that the desire of dictators to eliminate signs of discontent even before "sham" elections may account for increases in spending and deficits in non-democracies that they report. Alternative explanations of pre-election fiscal expansions that might be observed under both competitive and non-competitive electoral systems would include multi-year economic plans which coincide with the term of governments or "end of term" budgeting effects.

${ }^{8}$ It is too simple to argue that including non-democratic countries in the sample simply lowers the probability of finding significant results. The model should be tested separately for democracies and other countries.
} 
and the former Soviet Union (for the period 1990-2001), and all others. Tables A1 and A2 provide a list, as well as a description of the available data for each country. ${ }^{9}$

An important feature of the data is that the number of countries in the sample is increasing over time. This feature reflects not only the expanded coverage of the IFS, but also an increase in the number of democracies. Using the POLITY filter to identify democracies, we find that there are 31 democracies in the sample in the 1960s; 44 in the 1970s, 53 in the 1980s, and 59 in the 1990s, not counting the formerly socialist economies. If the transition economies are included the number of democracies rises to 69 in the 1990s, more than twice the number in the 1960s. More specifically, new democracies are being added to each of the samples over time.

The basic regression is of the form:

$$
f_{i, t}=\sum_{k} \mathrm{~b}_{k} f_{i, t-k}+\sum \mathbf{c}^{\prime} \mathbf{x}_{i, t}+\mathrm{d} E L E C_{t}+\mu_{i}+\varepsilon_{i, t}
$$

where $f_{i, t}$ is a fiscal indicator in country $i$ in year $t, \mathbf{x}_{i, t}$ is a vector of control variables, $E L E C_{t}$ is an electoral dummy, and $\mu_{i}$ is a country fixed effect. (Year effects were generally insignificant and were dropped from the regressions. ${ }^{10}$ ) In the tables, we present only the coefficient of the electoral variable, indicating whether or not there is a statistically significant political cycle.

In addition to fixed country effects, our control variables are those used by Persson and Tabellini, which encompass those commonly used in the literature. These include real GDP per capita taken from the 2002 version of the World Bank's World development Indicators dataset (WDI)), the trade share, two demographic variables representing the fraction of the population aged 15-64 and 65+ (also taken from WDI), and the log difference between real GDP and its (country specific) trend (computed using the Hodrick-Prescott filter), as a measure of the output gap.

The electoral dummy, meant to capture pre-electoral effects, is that used by these authors. It equals 1 in an election year and 0 otherwise, no matter when during the year

\footnotetext{
${ }^{9}$ Table A3 lists countries that were excluded, either because: IFS data doesn't exist, even though some other studies include these countries; IFS data exist, but they were not democracies; or, because, though the country is democratic, we judged the IFS data to be of very low quality. ${ }^{10}$ The insignificance of the year effects may be due to the inclusion of controls for the level of economic activity in each country in each year.
} 
the election occurred. ${ }^{11}$ However, we adjust the electoral year definition to be consistent with the fiscal year, when fiscal data are reported for a fiscal year different than the calendar year. Election dates and institutional data on the election process are taken from the DPI dataset, provided by the World Bank (Beck et. al., [2001], Keefer [2002]). These data were complemented, where needed, by other political datasets, such as the IDEA (Institute for Democracy and Electoral Assistance, "Voter Turnout Since 1945 to Date") and IFES (International Foundation for Electoral Systems, election guide).

Using country fixed effects in an OLS regression with lagged dependent variables introduces a potential estimation bias that is of order $1 / T$, where $T$ is the length of the panel. (See, for example, Nickell [1981] or Wooldridge [2002].) The bias arises because the initial condition $f_{i, 0}$ is correlated with the country fixed effect $\mu_{i}$, so that the lagged dependent variable is correlated with the error term. This problem is thought to be especially severe in micro panel data, where the number of individuals $i$ is large, while $T$ is quite small, often less than half-a-dozen. Since the potential bias of the fixed effects estimator is of order $1 / T$, the magnitude of the bias in our estimates reported below depends on which sample and fiscal indicator we use. In a panel of all democracies from 1960-2001, the average length of the sample is 24 years in the whole sample, 34 years in the developed country subsample, and 18 years for less-developed country subsample. (Remember that some countries do not have data for the entire period.) The average length of the time series in our panel of "old" democracies is longer - 35 years, with few countries having a time series shorter than the maximum. Hence, the bias from using a fixed effects estimator in these regressions is likely to be small.

The potential bias may be greater in the panel of elections in "new democracies", since by definition the sample length is much shorter (12 years including transition economies, 13 years excluding them). To address this problem we also present GMM estimates for the subsample of new democracies, using the Arellano-Bond procedure. ${ }^{12}$

In the first column of Table 1, we present fixed-effects regressions for the fiscal balance, revenues and expenditures, all as a percentage of GDP. We present only the

\footnotetext{
${ }^{11}$ See Table 9 and the associated discussion for the effect of splitting the electoral dummy into elections that occurred in the first half of the year and those that occurred in the second half of the year. We consider the endogeneity of election dates in section 5 below.

${ }^{12}$ Wooldridge (2002) discusses the advantages and disadvantages of the two methods.
} 
coefficient on the electoral variable, indicating the presence or absence of a political cycle. We find a highly significant political cycle in the fiscal balance, with the deficit rising in an election year by about three-tenths of one percent of GDP relative to nonelection years. $^{13,14}$

\section{The Empirical Importance of Being a New Democracy}

As mentioned above, the number of democracies in the sample increased substantially as more countries, both developed and less-developed, became democracies. Whether a country is a new or established democracy may have a significant effect on the likelihood that incumbents would use pre-electoral fiscal manipulation to increase the probability of their re-election. Many models arguing that voters hold incumbents accountable for deficits and wasteful spending would predict that incumbents who value office would cut rather than increase spending, especially in developed economies, where government expenditure is high relative to GDP. (See Peltzman (1992) Besley and Case (1995), Alesina, Perotti and Tavares (1998), among others.) For this to be the case, one would require, however, that voters have both the necessary information to draw such inferences, as well as the ability to process that information correctly. These would reflect experience with the electoral process by voters, the establishment of the institutions that would collect and provide the relevant data, and experience by media in disseminating and analyzing this information. In the absence of this experience, it is more likely that fiscal manipulation would be rewarded rather than punished, so that incumbents would engage in it. We will return to these arguments in more detail in section 5 below.

Another reason why the interpretation of economic data by voters may be more complicated in new democracies is the shift in economic structure that often goes along

\footnotetext{
${ }^{13}$ The qualitative results in these and all other regressions do not significantly change when the White Heteroskedasticity Consistent Covariance correction is used to calculate standard errors.

${ }^{14}$ These results correspond to those found in studies such as Shi and Svensson (2002a, $2002 \mathrm{~b}$ ), who considered a cross-section of both democracies and non-democracies over the period 1975-95. When we used a sample without a democracy filter over the same twenty year period with their control variables, we found a significant coefficient of -.632 with an FE estimator, insignificantly different from their coefficient of -.49 . When we ran their regression over the entire sample period using only democracies, the coefficient was -.325 .
} 
with the shift to democracy. This is perhaps most striking when one considers the formerly socialist economies in Eastern Europe and the former Soviet Union where the centrally planned economic system and the reporting mechanisms were abolished in a relatively short period. The collapse of old economic systems may also present a problem in the analysis of the political fiscal cycle in these countries: to the extent that high deficits associated with the economic transition occur simultaneously with the political transition, without either one causing the other, one would not classify this as a classic political fiscal cycle. On the other hand, politicians facing the new phenomenon of contested elections who are aware of the desire for rapid economic transition may respond especially strongly with deficit spending. ${ }^{15}$

To test this hypothesis that political budget cycles are more prevalent in "new democracies", we separate them from established democracies in our sample. Using the POLITY filter, we separate those countries that had competitive elections during the entire sample period for which we have data from those that began having competitive elections only within the sample period. For the latter, we take observations for the first four competitive elections and define those observations as coming from a "new democracy". ${ }^{16}$ In Table A2, we list those observations characterized as "new democracies" in both the sample of developed and less developed countries. Table A4 provides a breakdown of all the elections in our sample according to the various country classifications.

In the second and third columns of Table 1, we present results over only new democracies in the sample both including and excluding the new democracies in Eastern Europe (columns 2 and 3, respectively). The fourth column of the table presents results

\footnotetext{
${ }^{15}$ This suggests that one needs to be careful in how one treats the transition economies in the first years after transition, and in how one interprets the results of any study that simply lumps them together with other countries. To err on the safe side, we exclude all the elections that took place in the first two years following the transition.

${ }^{16}$ An alternative characterization of elections in a new democracy is those elections that occur within a specific time period after the country became democratic. We tried alternative definition of all elections in the first 10 years and the first 15 years after becoming democratic. The results (available on request) are very similar, not surprisingly, since generally the same elections are being captured.
} 
for only old, that is, established, democracies (that is, all countries which were in a sample of democracies using the POLITY filter, excluding the new democracies). ${ }^{17}$

Because of the short sample length in the new democracy panels, there is a possible bias in using a fixed effects estimator including lagged dependent variables. In table 2 we therefore present GMM estimates of the new democracy regressions, using the methodology of Arellano and Bond (1991). (In the table, we also present the regressions for all and only old democracies for comparison purposes, though the length of the time series in these samples implies no significant bias in the fixed effects estimates.)

A number of results stand out. First, we find a significant deficit cycle for the set of new democracies, whether or not the formerly socialist economies are included. The coefficients on the electoral variable are larger than in the sample of all democracies. We also find, in contrast to all other results presented so far, that there is a significant political expenditure cycle in the new democracies (as suggested, for example, by Schuknecht [1996]). Note, moreover, that the coefficients on the fiscal balance and on expenditures in the analogous equations are very similar (and of opposite sign), while the coefficient on revenues is smaller in absolute value and not significantly different from zero. The deficit cycle in the new democracies appears to be clearly driven by higher election-year expenditures. When the sample includes only established democracies, there is no significant deficit cycle, but a significant revenue cycle not present in the sample of all democracies. Revenues fall in an election year, similar to what was found by Persson and Tabellini.

To further test the "new democracy" effect, we run regressions for the sample as a whole, that is, both new and old democracies, including separate dummy variables for each of the first four elections, a dummy for all elections in old democracies and a dummy for all elections after the fourth in "former" new democracies. The results are

\footnotetext{
${ }^{17}$ There are two ways one may exclude elections in "new democracies" in testing for a political cycle in "old" democracies. One is to exclude all elections (i.e., all observations) that is, to exclude those countries that made the transition to democracy in the sample period entirely. The other is to exclude only those election observations which occurred when the democracy was in fact "new" (up to the first four elections after the transition to democracy in our definition), but to include all other observations for these countries in a sample of elections in old democracies. As we cannot be sure a priori how long the new democratic effect persists (we take four elections as a possible minimum), we prefer the first procedure and present results using that procedure. We ran the regressions using the second definition of "old" democracies and found the same results.
} 
presented in Table 3. Each of the four new election dummies is significant in regressions for a fiscal balance cycle, with approximately equal magnitude, while the coefficients on the dummies for elections after the fourth in new democracies and in elections in old democracies are not significant. Moreover, starting with the second election in new democracies, the significance of the coefficient drops as one moves to the third and fourth elections, suggesting that electoral fiscal effects may be becoming less strong in new democracies as there is more experience with elections. Analogous to our other results there is no significant political cycle in revenues or expenditures when separate election dummies are used.

To summarize, the political deficit cycle is a phenomenon of new democracies. The finding of a statistically political deficit cycle in a cross-section of all democracies is due to the first few elections in countries that are new democracies. Once these are removed from the sample and only elections in established democracies are considered, the political deficit cycle as a statistically significant phenomenon in aggregate data disappears.

We should stress that we are not arguing that fiscal manipulation does not occur at all in other countries, but only that it is not sufficiently prevalent and large to show up as an econometrically significant regularity in the aggregate fiscal deficit for groups of countries other than new democracies. Of course, there may be incidents of aggregate fiscal cycles in other countries, as well as fiscal manipulation other than fiscal expansion that is not observable in the aggregate fiscal data. But, in terms of aggregate fiscal expansion, it is the new democracies where the political budget cycle is really occurring.

\section{Country, Government, and Electoral Characteristics}

Many empirical studies of the political budget cycle across countries argue that the strength of cycle depends on a country's economic or political characteristics. Such arguments include: the level of economic development (see section 2 above), whether elections dates are predetermined or not (Shi and Svensson, 2002b), constitutional rules determining electoral rules and form of government (Persson and Tabellini, 2002, 2003), the "level" of democracy (Shi and Svensson, 2002a, Gonzalez 2002), or other measurable factors such as "transparency" or rent-seeking (Shi and Svensson, 2002a, Alt and Lassen, 
2003). In this section we consider some of these arguments. For each of the first four arguments, we show that significant finding of a deficit cycle are driven by the experience of new democracies.

\section{A. Developed versus Less Developed Countries}

We first consider developed and less developed countries separately. As already indicated, until recently the political budget cycle was thought to be a phenomenon largely of less developed countries. Shi and Svensson found a cycle in both developed and less-developed countries, but argued that the cycle was significantly stronger in the latter.

Corresponding roughly to a set of developed countries are members of the OECD for the entire sample period. There are four "new democracies" in the sample period in this group - Greece, Portugal, Spain, and Turkey. While there are not enough data points to test for a political fiscal cycle in a sample of only new democracies, we can estimate the equations both with and without these four countries. In columns 1 and 2 of Table 4 , we present results for the political fiscal cycle in OECD countries. What we find is that once the new democracies are removed from the sample, so that the sample contains only established democracies, the fiscal balance cycle found in the group of OECD countries as a whole disappears. Similar to what was found for the sample as a whole, there is a statistically significant revenue cycle in OECD established democracies. Hence, as before, the political deficit cycle in new democracies is driving the results for the sample of OECD countries as a whole.

In columns 3, 4, 5, and 6 of Table 4, we consider the political fiscal cycle in lessdeveloped countries (strictly speaking, countries which were not in the OECD at the beginning of the sample period.) The regressions correspond to all LDC democracies, LDC new democracies with both FE and GMM estimation, and LDC old democracies.

As in the case of developed countries, there is a statistically significant deficit cycle in the LDC sample as a whole, but it is due to the new democracies. We also find that the deficit in the new democracies is driven by higher expenditures in election years. No statistically significant political deficit or revenue cycle is found in the subset of established LDC democracies. 


\section{B. Pre-determined election dates}

The strength of the political budget cycle may also depend on whether the election date is pre-determined or not. Although one might think that fiscal manipulation in the year of an election will be stronger when the election date is exogenously fixed by law, there are two conceptual problems with such a simple presumption.

First, the distinction between electoral systems where the election date is exogenously fixed and systems where early elections may be called is not as clear cut as it may at first appear. In many countries fixed election periods are set and early elections may only be called under "exceptional circumstances", but in fact early elections are the rule rather than the exception. That is, what determines "exceptional circumstances" may in practice be quite different than what appears to be the case from a simple reading of the election laws. Since almost all countries have some provision for elections at a date earlier than the end of the legally mandated term of office for the executive or the legislature, whether the elections actually occur at the legally determined date is an empirical question. By the same token, there are countries where the government may call early elections, but rarely does.

Second, we believe that there is no clear theoretical presumption about whether fiscal manipulation will be stronger or weaker when election dates are effectively predetermined. When the election date is known well in advance, an opportunistic incumbent has ample opportunity to use fiscal policy to help his re-election, far greater, it would seem than if there are "snap" elections, with a short lag between elections being called and being held. On the other hand, since incumbents can largely control the timing of endogenous elections, there may be more scope for fiscal manipulation. As argued in the introduction, it is extremely difficult to fine tune when policy will have the desired effect; the option of early elections with a short campaign period may allow elections to be held roughly when the economy looks best ${ }^{18}$. Knowing this, incumbents may be more

\footnotetext{
${ }^{18}$ Heckelman and Berument (1998) find, for example, that election dates in Japan and the U.K. are endogenous.
} 
tempted to use fiscal policy in the attempt to affect voting behavior. ${ }^{19}$ Conversely, deterioration in the fiscal situation may create a majority for replacing the government and hence lead to a call for early elections.

One way to address the endogeneity bias from reverse causation or from shocks affecting both the election date and the fiscal balance is to separate out those elections whose timing is pre-determined. We do this by looking at the constitutionally determined election interval taking as predetermined those elections which were held either at the fixed interval or within the expected year of the constitutionally fixed term.

The results are presented in Table 5. In column1 of the table, we report the results for the sample of all democracies using an OLS fixed-effects estimator. We find that the coefficient on the electoral variable is similar in size and statistically significant for both pre-determined and endogenous election dates. In columns 2 and 3, we restrict the sample to only new democracies, using a fixed-effects and a GMM estimator, respectively. The coefficient is significant for both pre-determined and endogenous election dates using either method. There is no significant political cycle in established democracies either for pre-determined or for endogenous election dates.

To summarize, we find a deficit political cycle in "new" democracies, but not in established democracies, regardless of whether elections were pre-determined or took place before their scheduled date. We also find a significant expenditure cycle in "new" democracies for the case of endogenous election dates and a revenue cycle in predetermined elections in old democracies. Taken as a whole, the results suggest that our finding that the political budget cycle found in large samples is due to new democracies is not caused by the endogeneity of election dates.

\section{Constitutional Rules}

Persson and Tabellini (2003) argue that fiscal policy outcomes depend significantly on the nature of the government system - whether a country has a parliamentary or presidential system of government and whether voting for the legislature was primarily via proportional or majoritarian rules. In a number of papers they consider

\footnotetext{
${ }^{19}$ The view that there is no clear theoretical presumption of the effect in one direction or the other is consistent with the results of Shi and Svensson. They find that the coefficient on the fiscal balance was similar across countries with predetermined versus endogenous election dates.
} 
the importance of constitutional rules on fiscal policy in general and find significant empirical differences in fiscal policy outcomes across systems. Persson and Tabellini (2002, 2003, chapter 8) focus is on differences in political budget cycles across government systems and find differences in the cycle across systems.

Following their differentiation of systems, we considered the difference in the political budget cycle across these four categories. There are in fact differences in the deficit cycle across systems when one considers the sample of all democracies. However, similar to our earlier results, we find that these differences reflect the experience of new democracies.

The results on differences between presidential and parliamentary systems are presented in Table 6, where the classification follows Persson and Tabellini. We split our electoral dummy into two: one for elections in parliamentary systems, the other for elections in presidential systems. In column 1 of the table we show that in the sample of all democracies, there is a significant deficit cycle in both presidential and parliamentary systems. As before, when we separate new from old democracies, we find that the deficit cycle exists only in the former. Interestingly, the statistically significant revenue cycle which we found in some earlier specifications for established democracies is a phenomenon of parliamentary established democracies, as we see comparing the columns.

In Table 7 we compare the effect of proportional versus majoritarian voting rules on the political budget cycle. In column1 we show that in the sample of all democracies, the deficit cycle is significant only in those countries that use proportional voting rules. The coefficient for majoritarian systems is similar, but it is not statistically significant. As before, when we separate the sample into new and old democracies, we find a strong and significant cycle in new democracies with proportional systems, but no significant cycle in the analogous old democracies. Moreover, we also find that the cycle reflects increased expenditures during election years in the new democracies. Hence, we find that the electoral rule matters, consistent with Persson and Tabellini's arguments, but only in the group of countries where the fiscal cycle exists to begin with, namely, the new democracies. $^{20}$

\footnotetext{
${ }^{20}$ We note, however, that our sample includes only 19 majoritarian elections in new democracies.
} 


\section{Level of Democracy}

Another hypothesis is that it is not the length of time a country has been a democracy, but the level of democracy that matters for the existence of a political fiscal cycle. That is, the political fiscal cycle may be a phenomenon of countries where democracy is relatively weaker. (See, for example, Shi and Svensson [2002a] and Gonzàlez [2002].) To examine this, we compare the political budget cycle in countries with a lower level ("quality") of democracy to those with a higher level. Specifically, we once again split the electoral dummy into two: Elect-high takes a value 1 in an election year if the POLITY value is between 0 and 9 and a value of 0 otherwise; and Elect-low, which takes a value 1 in an election year if the POLITY value is 10 and a value of 0 otherwise. $^{21}$

The results for the sample as a whole and for new and old democracies separately are given in Table 8. In the first column, we indeed find that the political budget cycle is stronger in countries with a lower level of democracy. The deficit cycle is significant in those countries where the POLITY index of democracy is between 0 and 9 , whereas it is insignificant in countries with a POLITY index of 10.

However, once we separate old democracies from new democracies we find that the apparent effect of the level of democracy is entirely due to the new democracies. In the second and third columns in Table 8 we show that for new democracies, the deficit cycle is significant, regardless of the level of democracy. In contrast, in the last column, where we consider only established democracies, we find that there is no political budget cycle, once again regardless of their level of democracy.

The reason we find stronger evidence for a political budget cycle in the sample of all countries when we condition on the level of democracy is probably a composition effect. The proportion of new democracies in the group of lower "quality" democracies is significantly higher: 50 percent of the data points in that group, compared to 7 percent among the countries with a high level of democracy (See also Table A4). The findings in

\footnotetext{
${ }^{21}$ In some countries the POLITY index changed over time, in which case we split the observations for the country between the groups according to the index in each year.
} 
Table 8 also rule out the explanation that the results for new democracies actually reflect their lower level of democracy, rather than their being "new".

\section{E. Election Dates}

Following much of the empirical literature, our election dummy was equal to one in the year of an election no matter when in the year the election took place. If the election took place late in the year, then the dummy indeed captures mostly the period before the election. However, if the election took place early in the year, then the dummy may be capturing, for the most part, post-electoral effects. ${ }^{22}$

One way to address this problem with annual data is to define the dummy as equal to one in the year before the election if the election took place in the first half of the year, and equal one in the year of the election otherwise. However, this covers a time period so far before the election in the first case (and may still miss the few months nearest to the election) that the dummy may also be a poor indicator of pre-electoral effects, especially if fiscal manipulation to gain votes is strongest in the months right before an election as suggested, for example, by Akhmedov and Zhuravskaya (2003). Optimally, one would like to have high-frequency data if electoral manipulation is short-lived. However, since this is not possible in a large cross-section study, these considerations suggest that any electoral dummy used with annual data (as must be) might be quite "noisy" for cases where elections are held in the first part of the year. Hence, rather than re-defining the electoral dummy as discussed above, we split the dummy into two, one for elections held in the first half of the fiscal year, the other for elections held in the second half.

The results of our estimation with the dummies are presented in Table 9. We find that for elections held in the second half, where we believe the variable is less noisy, there is a deficit cycle in the sample as a whole that is due to the new democracies. The coefficient estimates are larger than those reported in Table 1. There is no cycle in old

\footnotetext{
${ }^{22}$ We also tested directly the existence of a post-electoral effect by adding a dummy variable for the year after elections. The coefficient was not statistically significant in almost all the equations, did not affect the significance of any of our new democracy results, and eliminated the significance of the revenue coefficient in the old democracies, except for those with parliamentary elections.
} 
democracies. In contrast, for elections held in the first half of the year, there is no significant cycle in any sample, which we attribute to the noisiness of the dummy in this case.

\section{The New Democracy Effect}

Why are new democracies more susceptible than established democracies to election-year economics at the aggregate level? It is beyond the scope of this paper to investigate this question in any depth, though our results, as well as those of others, may suggest some avenues of research.

Whether election-year deficits are rewarded or punished at the polls may depend on the availability of information - including the existence of media that would deliver such information to voters. (See, for example, Brender [2003]). An incumbent might be rewarded at the polls only if he can hide the manipulation and make the public believe that the good economic conditions reflect the success of his policy or his high ability. This assumption seems unreasonable in many countries because voters - especially experienced ones (who understand the incentives and the tools of electoral manipulation) - know that election years are particularly "suspect" for manipulation and therefore would interpret "surprises" in these years with special caution. Therefore, in economies in which the electorate has a lot of experience with elections, and where the collection and reporting of the relevant data to evaluate economic policy are common, voters would be unlikely to "fall" for the trick of making the economy look good right before elections.

In contrast, fiscal manipulation may work when voters lack the necessary information to draw such inferences, as well as the ability to process that information correctly. This would reflect a lack of experience with an electoral system, of the availability of data, and of media experienced in finding, disseminating and analyzing the relevant data. This is more likely to characterize a new democracy. ${ }^{23}$

We want to stress that the ability to draw inferences about incumbent performance from pre-electoral economic variables is not meant simply to represent the experience of voters, but of experience and interactions of all actors with the electoral system. Put

\footnotetext{
${ }^{23}$ If "pivotal" voters are harder to identify in a new democracy, then transfers meant to woo voters may be spread more widely, implying higher aggregate government deficits. We are indebted to Alessandra Casella for this suggestion.
} 
another way, it is not that new democracies are characterized by unsophisticated or naïve voting population, but that in countries with less of an electoral history, and hence less exposure to pre-electoral fiscal manipulations, a political cycle is more likely to occur. In many new democracies, even basics like the collection of data and reporting it to the public are not well established, so that fiscal manipulation is easier to engage in. (The demand for data may in fact be driven in part by the possibility of holding office-holders accountable through elections.)

Some recent papers found evidence consistent with this view in specific countries. Brender (2003) shows how the electoral response to deficit spending in local Israeli elections changed dramatically over the period $1989-1998$. He found that when direct elections for mayors were introduced in Israel, voters were initially indifferent to deficits and local fiscal management. By the 1998 elections, however, when accounting and reporting standards were enforced on the local authorities, and when the local media expanded, deficit spending was "punished" at the polls.

A very recent paper by Akhmedov and Zhuravskaya (2003) found similar evidence in regional elections in Russia after its transition to democracy. Using monthly data between 1996 and 2003, they found a sizable, but short-lived political budget cycles in which large expansions and contractions in local fiscal spending occur in the two months before and after elections. They find that the magnitude of the cycle becomes smaller over time and that an additional election in a region reduces the magnitude of the cycles by over $30 \%$, so that each new round of regional elections had substantially smaller cycles, with the cycle disappearing for most (but not all) fiscal instruments after two rounds of elections.

A number of papers have considered the role of transparency more formally and may thus shed further light on one important characteristic of new democracies. Gonzàlez (1999) and Shi and Svensson (2002a) extend Rogoff's model to study the effect of the degree of democracy and the level of institutions on the magnitude of fiscal cycles. Both models stress the importance of "transparency," which ultimately means the probability that voters learn the incumbent's characteristics costlessly, that is, independent of signaling. The higher the degree of transparency, the smaller is the political budget cycle. 
Shi and Svensson further argue that while the proportion of uninformed voters who may be influenced by fiscal manipulation - is initially large, it is likely to decrease over time, thus decreasing the magnitude of budget cycles. They create a measure of the availability of information and show that as voters become more informed the magnitude of the cycle decreases. ${ }^{24}$

Other papers also find that greater transparency is associated with smaller political cycles. Akhmedov and Zhuravskaya (2003) find similarly that measures of the freedom of the regional media and the transparency of the regional governments were important predictors of the magnitude of the cycle. Alt and Lassen (2003) find that in OECD countries, higher fiscal transparency also lowers the magnitude of the electoral cycle. All these results are consistent with ours if lack of transparency or information, as measured by these papers, is an important characteristic of new democracies.

One should also note an essential difference between some of these arguments and ours. Whereas Shi-Svensson and Gonzàlez, for example, view transparency primarily as a characteristic of political systems (that may evolve over time, with institutional change or development), our new democracy results suggest a somewhat different view. "Transparency" reflects experience with the elections themselves, with the crucial variable being the number of competitive elections a country has held (or, the length of time a country has been a democracy), rather than the level of democracy. Our findings in Table 8, namely that the importance of the level of democracy in explaining the cycle may actually reflect the new democracy effect, suggest the importance of distinguishing the two. A key implication of our view is that the signal content of fiscal actions necessarily changed over time as voters became more experienced over time with electoral fiscal manipulation and were provided with more economic and fiscal information in order to draw inferences. This is certainly consistent with the findings of Akhmedov and Zhuravskaya (2003) discussed at the beginning of this section. Hence, any positive effect of deficit spending on an incumbent's electoral prospects would not only diminish over time, but would probably change sign as a country has more experience with a competitive electoral process.

\footnotetext{
${ }^{24}$ The index is a product of the number of radios per capita and a binary variable of whether the country had freedom of broadcasting.
} 
This last point brings us back to the relation between the theory of the opportunistic political business cycle, predicated on the view voters may reward deficit spending at the polls, and the view that voters may punish deficit spending at the polls.

Our results for new democracies are consistent with the first view, while the findings for established democracies are consistent with the second. Proponents of the latter view, such as Peltzman (1992) or Alesina, Perotti, and Tavares (1998) looked at established democracies, and it is not surprising that they do not find support for an electoral benefit of deficit spending. Our new democracy result - and the view that there is a learning process which leads to the empirical disappearance of an aggregate political budget cycle - can reconcile and make consistent these two approaches.

An implication of the argument that voters in established democracies may punish deficit spending is that opportunistic politicians will use fiscal policy to influence voters in ways that don't increase the overall budget deficit. This may be by changing the composition of expenditures in an election year in a way designed to get more votes, or, more specifically, by targeting particular groups of voters. Drazen and Eslava (2004a) present a model of rational voter in the first case and present evidence on the importance of composition of spending effects for the political budget cycle in regional and municipal elections in Colombia. In Drazen and Eslava (2004b), it is shown that when rational but imperfectly informed voters must infer whether they are targeted for election purposes are not, effective fiscal manipulation can take place without increasing the government budget deficit.

\section{Conclusions}

In this paper we considered the empirical evidence for the existence of a political budget cycle. The question of whether such a cycle exists on the macroeconomic level across countries turns out to be a question of where it exists, that is, in which types of countries. The answer to that question is not only empirically relevant, but theoretically important as well, since it sheds light on what factors may account for the existence of a cycle.

Our empirical results indicate that the political deficit cycle is a phenomenon of new democracies. The strong political cycle in those countries, which is characterized by 
increased expenditures in election years, accounts for the finding of a political deficit cycle in larger samples including these countries. Once these countries are removed from the larger sample, the political deficit cycle in larger samples disappears. Furthermore, our results indicate that empirical findings of stronger cycles in less-developed than developed countries, in countries with lower levels of democracy, or across government systems and electoral rules is driven by the experience of new democracies.

This finding suggests that fiscal manipulation is used more broadly in "new" democracies, where it may "work" because of lack of experience with electoral politics or lack of information that is available in established democracies and used by experienced voters. As models that view rational voters as "fiscal conservatives" suggest, once a country becomes experienced in electoral politics, the scope for a political fiscal cycle at the aggregate level should be diminished, perhaps significantly so. 


\section{REFERENCES}

Akhmedov, A. and Zhuravskaya, E. (2003), "Opportunistic Political Cycles: Test in a Young Democracy Setting,” working paper. (Corresponding author: zhuravsk@,ias.edu)

Alesina, A., G. Cohen, and N. Roubini (1992), "Macroeconomic Policy and Elections in OECD Democracies" Economics and Politics 4, 1-30.

Alesina, A., R. Perotti and Tavares (1998), "The Political Economy of Fiscal Adjustments," Brookings Papers on Economic Activity 1:1998.

Alesina, A., N. Roubini, and G. Cohen (1997), Political Cycles and the Macroeconomy, Cambridge, MA: MIT Press.

Alt, J.E. and D. Lassen (2003), "Fiscal Transparency, Political Parties, and Debt In OECD Countries,” working paper. (jalt@,latte.harvard.edu)

Ames, B. (1987), Political Survival, Berkeley, CA: University of California Press.

Arellano, M. and S. Bond (1991), "Some Tests of Specification for Panel Data: Monte Carlo Evidence and an Application to Employment Equations," Review of Economic Studies 58, 277-297.

Beck et al., (2001), World Bank Database on Political Institutions.

Ben-Porath, Y. (1975), "The Years of Plenty and the Years of Famine -- A Political Business Cycle," Kyklos 28.

Besley, T. and A. Case (1995), "Does Political Accountability Affect Economic Policy Choices," Quarterly Journal of Economics 110, 769-798.

Block, S. (2000), "Political Business Cycles, Democratization, and Economic Reform: the Case of Africa," working paper, Fletcher School, Tufts University.

(2002), "Elections, Electoral Competitiveness, and Political Budget Cycles in Developing Countries," working paper, Fletcher School, Tufts University.

Brender, A. (2003), "The Effect of Fiscal Performance on Local Government Election Results in Israel: 1989-1998," Journal of Public Economics, 87, 2187-2205.

Drazen, A. (2000), Political Economy in Macroeconomics, Princeton, NJ: Princeton University Press.

(2001), "The Political Business Cycle After 25 Years" NBER Macroeconomics Annual 2000 Cambridge, MA: MIT Press. 
Drazen, A. and M. Eslava (2004a), "Political Budget Cycles without Deficits: Expenditure Composition Effects," working paper. (ㅁazen@econ.umd.edu)

(2004b), "Political Budget Cycles when Politicians Have Favorites,” working paper.

Fair, R. (1978), “The Effect of Economic Events on Votes for President," Review of Economics and Statistics 60, 159-72.

(1982), "The Effect of Economic Events on Votes for President: 1980 Results," Review of Economics and Statistics 64, 322-25.

(1988), "The Effects of Economic Events on Votes for President: 1984 Update," Political Behavior 10, 168-79.

Gonzàlez, M. (1999), “On Elections, Democracy and Macroeconomic Policy Cycles,” working paper. (mgonzalez@imf.org)

(2001), "Do Changes in Democracy affect the Political Budget Cycle? Evidence from Mexico," Review of Development Economics 6.

Heckelman, J. and H. Berument (1998), "Political Business Cycles and Endogenous Elections," Southern Economic Journal, 64(4), 987-1000.

Keech, W. and K. Pak (1989), “Electoral Cycles and Budgetary Growth in Veterans' Benefit Programs," American Journal of Political Science 33, 901-11.

Keefer, P. (2002), DPI2000 Database of Political Institutions: Changes and Variable Definitions, The World Bank.

Krueger, A. and I. Turan (1993), "The Politics and Economics of Turkish Policy Reform in the 1980's," in R. Bates and A. Krueger, eds. (1993), Political and Economic Interactions in Economic Policy Reform: Evidence from Eight Countries, Oxford: Basil Blackwell.

Lewis-Beck, M. (1988), Economics and Elections, Ann Arbor: University of Michigan Press.

Madsen, H. (1980), "Electoral Outcomes and Macroeconomic Policies: The Scandinavian Cases," in P. Whitely, ed., Models of Political Economy, London: Sage, 15-46.

Nickell, S. (1981), "Biases in Dynamic Models with Fixed Effects," Econometrica 49, 14171426.

Peltzman (1992), "Voters as Fiscal Conservatives," Quarterly Journal of Economics 107, 32761.

Persson, T. and G. Tabellini (2002), "Do Electoral Cycles Differ Across Political Systems?” working paper, IIES, Stockholm University. 
(2003), The Economic Effect of Constitutions: What Do the Data Say?, Cambridge, MA: MIT Press.

Rogoff, K. (1990), “Equilibrium Political Budget Cycles,” American Economic Review 80, 2136.

Schuknecht, L. (1996), "Political Business Cycles in Developing Countries,” Kyklos 49, 155-70.

Shi, M. and J. Svensson (2002a), "Conditional Political Budget Cycles," CEPR Discussion Paper \#3352.

(2002b) "Political Business Cycles in Developed and Developing Countries," working paper, IIES, Stockholm University.

Tufte, E. (1978), Political Control of the Economy, Princeton NJ: Princeton University Press.

Wooldridge, J (2002), Econometric Analysis of Cross Section and Panel Data, MIT Press:

Cambridge, MA. 


\section{$\frac{\text { Data Appendix }}{\text { Sample }}$}

\section{Sample}

We use IFS data for all the countries with available central government data on the Deficit, Total Expenditure and Total Revenue (including Grants). Where IFS data are missing we tried to complement them by using GFS data or alternative sources. A detailed list of all the adjustments made to the data appears in Table A1.

To restrict our sample only to democracies, we include only the observations with a nonnegative score in the POLITY IV Level of Democracy index, which is produced by the University of Maryland. Hence, only data points with a score of 0 and above are left in the sample.

In the former socialist economies in Eastern Europe and the former Soviet Union we exclude the observations for the first two years after transition, as they may represent the simultaneous effect of the shift to democracy and the collapse of central planning, rather than political manipulation of fiscal variables. The elections in these countries which are included in the sample are listed in Table A2.

\section{Fiscal policy variables}

The dependent variables are the following: Balance-calculated as the difference between Total Revenue \& Grants and Total Expenditure. Total Expenditure- taken from the IFS dataset. Total Revenue \& Grants- calculated as Revenue plus Grants from the IFS dataset.

All these variables are presented as a percentage of GDP, the latter also taken from the IFS dataset.

\section{Election variables}

The data on election years and dates, are mainly retrieved from the Institute for Democracy and Electoral Assistance (IDEA), "Voter Turnout Since 1945 to Date" (www.idea.int/vt/index.cfm). Additional sources are: The International Foundation for Electoral Systems (www.ifes.org/eguide.elecguide.htm), The Database of Political Institutions (DPI) Version 2000, (a project conducted by the World Bank) and are complemented by other political data sources. See also www.electionworld.org. 
Our election year variable Elect- is a dummy variable that receives the value 1 in the election year and 0 otherwise.

All our estimations contain fixed country effects, as well as one lag of the dependent variable. Fixed year effects were tested and removed since they were not statistically significant and have not affected the main results.

\section{Economic control variables}

Trade- the share of international trade, as a percentage of GDP, taken from the World Development Indicators (WDI) 2002 publication of the World Bank.

Lgdp_p - the log of real per-capita income. The data for 1975-2001 are taken directly from the WDI dataset (mentioned above). The data for the years 1960-1975 are computed using the WDI "GDP per capita in constant 1995 US\$" series.

Pop1564, Pop65 - Two demographic variables measuring the fraction of a country's population, ranging between 15 through 64 , and above 65 , respectively.

Gdp_rhp - A measure of the output gap, calculated as the difference between real GDP and its (country specific) trend. The trend was computed using the Hodrick-Prescott filter on the change in real GDP. Real GDP data were extracted from the WDI dataset in constant 1995 US\$.

\section{Presidential Vs. Parliamentary constitutional rules}

The DPI database provides information whether the chief executive responsible for economic policy, in each country and in each election year, is elected directly by the public or by parliament. In the former case we define the electoral rule as Presidential and in the latter as Parliamentary, as in Persson and Tabellini (2002). Based on this distinction between the electoral rules we computed the following variables:

Pres - receives the value 1 in a Presidential electoral system, and 0 otherwise.

Parl - receives the value 1 in a Parliamentary electoral system, and 0 otherwise.

Elect_pres - an interaction between Pres and Elect $=($ Pres $) *($ Elect $)$.

Elect_parl - an interaction between Parl and Elect $=(\text { Parl })^{*}($ Elect $)$. 
When estimating the Presidential vs. Parliamentary equation, we use both Elect_pres and Elect_parl variables, together with the economic control variables, and one lag of the dependent variable.

\section{Proportional vs. Majoritarian electoral rules}

The DPI database provides information, in each country and in each election year, whether candidates are elected based on the percent of votes received by their party. In this case they define the electoral system as Proportional representation and in the other case we define the electoral system as Majoritarian representation. Based on the distinction between the electoral systems we computed the following variables:

Prop - receives the value 1 in a Proportional electoral system and 0 otherwise. Maj - receives the value 1 in a Majoritarian electoral system, and 0 otherwise.

Elect-prop - an interaction between Prop and Elect $=($ prop $) *($ Elect $)$

Elect-maj - an interaction between Maj and Elect $=(M a j) *(E l e c t)$.

\section{Level of democracy}

The analysis regarding the level of democracy was based on the score of each country in the POLITY IV dataset. We split the sample between these countries with a score of 0 to 9 and those with a score of 10 , because more than 50 percent of the data points represent countries with a score of 10 . Where the score changed during the covered period, we split the data points for that country according to the score in each year.

\section{Predetermined vs. Endogenous elections}

Based on www.electionworld.org data that indicate the frequency of elections country by country, we determined when the next elections should have been held. If the election were held in the expected year we classified them as predetermined; otherwise they were classified as endogenous. 
Table 1: The Political Budget Cycle Across Countries, Fixed Effects Estimates

\begin{tabular}{|c|c|c|c|c|c|c|c|c|c|c|c|c|}
\hline \multirow{4}{*}{$\begin{array}{l}\text { Estimation period } \\
\text { Dependent variable }^{1}\end{array}$} & \multicolumn{3}{|c|}{ All Democracies } & \multicolumn{3}{|c|}{ All "New Democracies" } & \multicolumn{3}{|c|}{$\begin{array}{l}\text { "New Democracies" Excluding } \\
\text { "Transition Economies"3 }\end{array}$} & \multicolumn{3}{|c|}{ "Old Democracies" } \\
\hline & \multirow{2}{*}{\multicolumn{3}{|c|}{$\frac{(1)}{1960-2001}$}} & \multirow{2}{*}{\multicolumn{3}{|c|}{$\frac{(2)}{1960-2001}$}} & \multirow{2}{*}{\multicolumn{3}{|c|}{$\begin{array}{c}\frac{(3)}{1960-2001} \\
\end{array}$}} & \multicolumn{3}{|c|}{$(4)$} \\
\hline & & & & & & & & & & & 1960-200 & \\
\hline & balance & texp & $\operatorname{trg}$ & balance & texp & $\operatorname{trg}$ & balance & texp & $\operatorname{trg}$ & balance & texp & $\operatorname{trg}$ \\
\hline Elect $^{2}$ & $\begin{array}{c}-0.341^{* * *} \\
(0.123)\end{array}$ & $\begin{array}{c}0.071 \\
(0.193)\end{array}$ & $\begin{array}{l}-0.263 \\
(0.170)\end{array}$ & $\begin{array}{c}-0.868^{* * *} \\
(0.273)\end{array}$ & $\begin{array}{l}0.745^{* *} \\
(0.292)\end{array}$ & $\begin{array}{l}-0.159 \\
(0.235)\end{array}$ & $\begin{array}{c}-0.685^{\star *} \\
(0.289)\end{array}$ & $\begin{array}{l}0.435^{*} \\
(0.259)\end{array}$ & $\begin{array}{l}-0.248 \\
(0.247)\end{array}$ & $\begin{array}{l}-0.092 \\
(0.133)\end{array}$ & $\begin{array}{l}-0.153 \\
(0.143)\end{array}$ & $\begin{array}{r}-0.239^{* *} \\
(0.117)\end{array}$ \\
\hline Adjusted $\mathrm{R}^{2}$ & 0.686 & 0.906 & 0.915 & 0.461 & 0.937 & 0.954 & 0.504 & 0.929 & 0.919 & 0.768 & 0.961 & 0.970 \\
\hline F-Statistic & 48.79 & 213.58 & 240.88 & 9.46 & 151.34 & 204.55 & 11.68 & 141.63 & 119.85 & 97.301 & 714.91 & 944.86 \\
\hline DW Statistic & 1.943 & 1.548 & 1.448 & 1.822 & 2.046 & 2.107 & 1.692 & 1.952 & 2.115 & 1.893 & 1.965 & 1.861 \\
\hline No. of countries & 68 & 68 & 68 & 36 & 36 & 36 & 26 & 26 & 26 & 32 & 32 & 32 \\
\hline No. of obs. & 1617 & 1632 & 1641 & 416 & 424 & 416 & 337 & 345 & 337 & 1105 & 1112 & 1128 \\
\hline Avg. time series length & 23.8 & 24.0 & 24.1 & 11.6 & 11.8 & 11.6 & 13.0 & 13.3 & 13.0 & 34.5 & 34.8 & 35.3 \\
\hline
\end{tabular}

The covariates include one lag of the dependent variable, the log of per-capita GDP, the ratio of international trade to GDP, the fraction of the population over age 65, the fraction of the population between ages 15 and 64, and the log difference between real GDP and its (country specific) trend, estimated using a Hodrick-Prescott filter.

${ }^{1}$ Variable definitions (all in percent of GDP):balance-central government surplus,texp-total expenditure by the central governmenttrg-total revenue and grants of the central government.

${ }^{2}$ Elect - a dummy variable with the value 1 in the election year and 0 otherwise.

${ }^{3}$ The "new democracies" among the transition economies are listed in Table A1.

* - Significant at the 10 percent level; ** - Significant at the 5 percent level; *** - Significant at the 1 percent level. 
Table 2: The Political Budget Cycle Across Countries, GMM Estimates.

\begin{tabular}{|c|c|c|c|c|c|c|c|c|c|c|c|c|}
\hline \multirow{4}{*}{$\begin{array}{l}\text { Estimation period } \\
\text { Dependent variable }\end{array}$} & \multicolumn{3}{|c|}{ All Democracies } & \multicolumn{3}{|c|}{ All "New Democracies" } & \multicolumn{3}{|c|}{$\begin{array}{l}\text { "New Democracies" Excluding } \\
\text { "Transition Economies"3 }\end{array}$} & \multicolumn{3}{|c|}{ "Old Democracies" } \\
\hline & \multirow{2}{*}{\multicolumn{3}{|c|}{$\begin{array}{c}(1) \\
1960-2001\end{array}$}} & \multirow{2}{*}{\multicolumn{3}{|c|}{$\begin{array}{c}(2) \\
1960-2001\end{array}$}} & \multirow{2}{*}{\multicolumn{3}{|c|}{$\begin{array}{c}(3) \\
1960-2001\end{array}$}} & \multirow{2}{*}{\multicolumn{3}{|c|}{$\frac{(4)}{1960-2001}$}} \\
\hline & & & & & & & & & & & & \\
\hline & balance & texp & $\operatorname{trg}$ & balance & texp & $\operatorname{trg}$ & balance & texp & $\operatorname{trg}$ & balance & texp & $\operatorname{trg}$ \\
\hline Elect $^{3}$ & $\begin{array}{c}-0.374^{* * *} \\
(0.109)\end{array}$ & $\begin{array}{l}0.217 \\
(0.173)\end{array}$ & $\begin{array}{r}-0.140 \\
(0.148)\end{array}$ & $\begin{array}{c}-0.739^{* * *} \\
(0.272)\end{array}$ & $\begin{array}{c}0.955^{* * *} \\
(0.339)\end{array}$ & $\begin{array}{l}0.299 \\
(0.394)\end{array}$ & $\begin{array}{c}-0.687^{* * *} \\
(0.259)\end{array}$ & $\begin{array}{l}0.592^{* *} \\
(0.253)\end{array}$ & $\begin{array}{l}-0.022 \\
(0.346)\end{array}$ & $\begin{array}{l}-0.191 \\
(0.123)\end{array}$ & $\begin{array}{l}-0.047 \\
(0.142)\end{array}$ & $\begin{array}{r}-0.223^{* *} \\
(0.106)\end{array}$ \\
\hline Sargan test ${ }^{4}$ & 0.001 & 0.998 & 1.000 & 1.000 & 1.000 & 1.000 & 1.000 & 1.000 & 1.000 & 0.000 & 0.000 & 0.000 \\
\hline $2^{\text {nd }}$ Order Test ${ }^{5}$ & 0.557 & 0.815 & 0.040 & 0.665 & 0.961 & 0.328 & 0.725 & 0.521 & 0.694 & 0.504 & 0.903 & 0.572 \\
\hline No. of countries & 68 & 68 & 68 & 36 & 36 & 36 & 26 & 26 & 26 & 32 & 32 & 32 \\
\hline No. of obs. & 1445 & 1458 & 1469 & 339 & 347 & 339 & 280 & 288 & 280 & 1028 & 1033 & 1051 \\
\hline Avg. time series lengtr & 21.3 & 21.4 & 21.6 & 9.4 & 9.6 & 9.4 & 10.8 & 11.1 & 10.8 & 32.1 & 32.3 & 32.8 \\
\hline
\end{tabular}

${ }^{1}$ Estimated using the Arellano-Bond procedure with two lags of the dependent variable. The covariates are as in table 1.

${ }^{2}$ Variable definitions (all in percent of GDP):balance-central government surplus;texp-total expenditure by the central governmenttrg-total revenue and grants of the central government.

${ }^{3}$ Elect - a dummy variable with the value 1 in the election year and 0 otherwise.

${ }^{4} \mathrm{P}$-values for rejecting the null hypothsis that the instruments are uncorrelated with the residuals.

${ }^{5} \mathrm{P}$-values for rejecting the null hypothsis that there is no second order serial correlationin the first-difference residuals.

* - Significant at the 10 percent level; ** - Significant at the 5 percent level; *** - Significant at the 1 percent level. 
Table 3: The Evolution of the "New Democracy" Effect Over Time."

\begin{tabular}{|c|c|c|c|}
\hline \multirow{3}{*}{$\begin{array}{l}\text { Estimation period } \\
\text { Dependent variable }\end{array}$} & \multicolumn{3}{|c|}{ All Democracies } \\
\hline & \multicolumn{3}{|c|}{$\frac{(1)}{1960-2001}$} \\
\hline & balance & texp & $\operatorname{trg}$ \\
\hline Elect_old ${ }^{3}$ & $\begin{array}{l}-0.100 \\
(0.145)\end{array}$ & $\begin{array}{l}-0.131 \\
(0.228)\end{array}$ & $\begin{array}{l}-0.223 \\
(0.201)\end{array}$ \\
\hline Elect_ND1 ${ }^{4}$ & $\begin{array}{c}-1.377^{\star *} \\
(0.543)\end{array}$ & $\begin{array}{c}0.751 \\
(0.833)\end{array}$ & $\begin{array}{l}-0.645 \\
(0.762)\end{array}$ \\
\hline Elect_ND2 ${ }^{4}$ & $\begin{array}{c}-0.816^{* *} \\
(0.384)\end{array}$ & $\begin{array}{c}0.441 \\
(0.590)\end{array}$ & $\begin{array}{l}-0.434 \\
(0.539)\end{array}$ \\
\hline Elect_ND3 ${ }^{4}$ & $\begin{array}{c}-0.973^{\star *} \\
(0.462)\end{array}$ & $\begin{array}{c}0.842 \\
(0.729)\end{array}$ & $\begin{array}{l}0.071 \\
(0.648)\end{array}$ \\
\hline Elect_ND4 ${ }^{4}$ & $\begin{array}{l}-1.169^{*} \\
(0.635)\end{array}$ & $\begin{array}{c}0.090 \\
(1.003)\end{array}$ & $\begin{array}{l}-1.038 \\
(0.892)\end{array}$ \\
\hline Elect_ND_LATER ${ }^{4}$ & $\begin{array}{l}-0.693 \\
(0.608)\end{array}$ & $\begin{array}{l}-0.180 \\
(0.962)\end{array}$ & $\begin{array}{l}-0.845 \\
(0.854)\end{array}$ \\
\hline Adjusted $\mathrm{R}^{2}$ & 0.687 & 0.906 & 0.915 \\
\hline F- Statistic & 46.98 & 199.80 & 225.27 \\
\hline DW Statistic & 1.945 & 1.545 & 1.452 \\
\hline No. of countries & 68 & 68 & 68 \\
\hline No. of obs. & 1617 & 1632 & 1641 \\
\hline
\end{tabular}

${ }^{1}$ Fixed Effects Estimates.For the list of covariates and variable definitions see Table 1.

${ }^{2}$ Variable definitions (all in percent of GDP)balance-central government surplus,texp-total expenditure by the central government; trg-total revenue and grants of the central government.

${ }^{3}$ Elect_old - a dummy variable with the value 1 in the election year - only in old democracies - and 0 otherwise.

${ }^{4}$ Dummy variables with the value of 1 in the election year of the first, second, third, fourth and later elections, respectively only in new democracies - and 0 otherwise.

* - Significant at the 10 percent level; ** - Significant at the 5 percent level; ${ }^{* *}$ - Significant at the 1 percent level. 
Table 4: The Political Budget Cycle in Developed and Less Developed Economies.

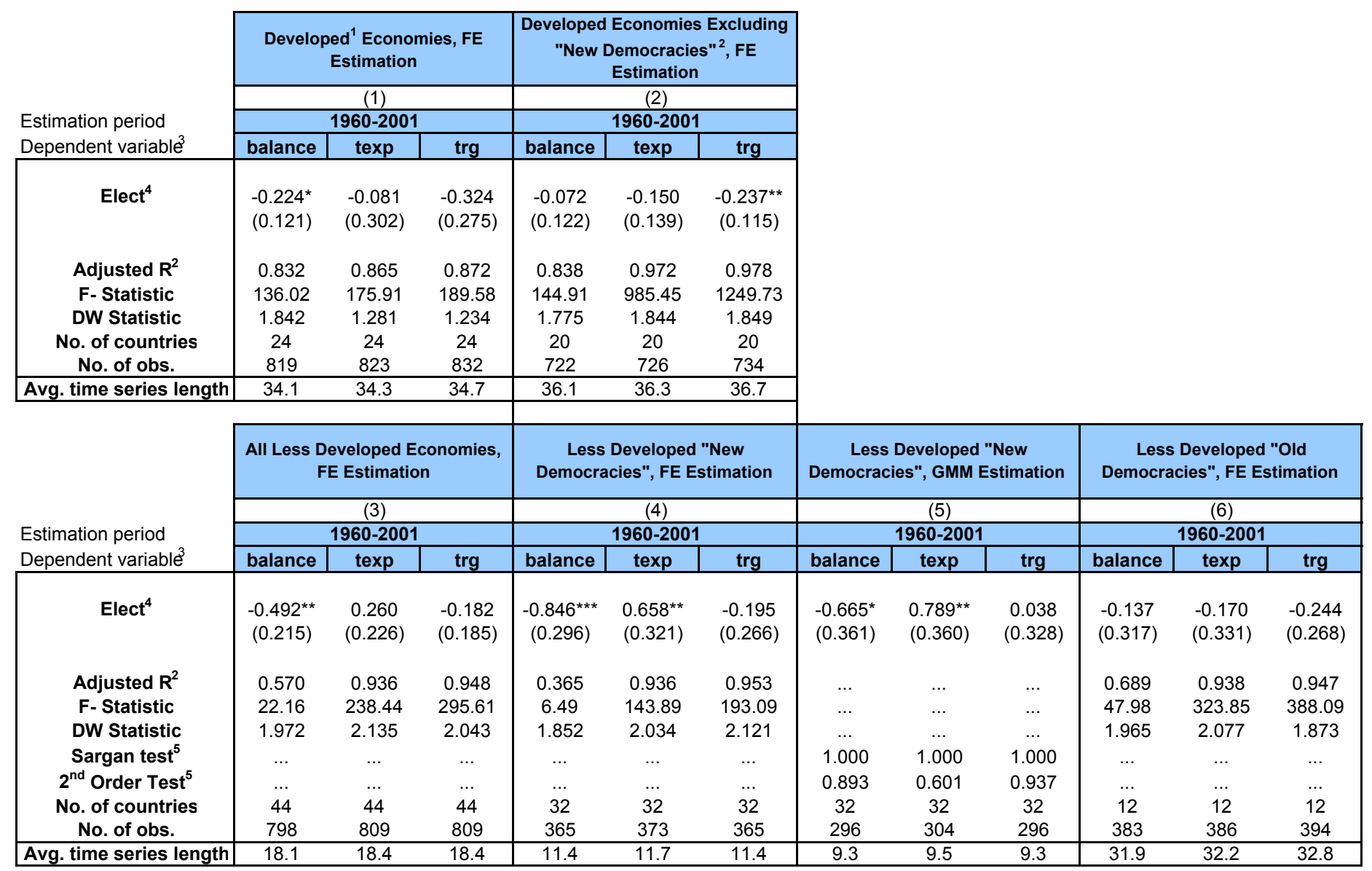

The covariates are as in table 1.

${ }^{1}$ OECD Economies that were members of the organization during the entire sample period.

${ }^{2}$ The "new democracies" among the developed economies are Spain, Portugal, Greece and Turkey.

${ }^{3}$ Variable definitions (all in percent of GDP):balance-central government surplus; texp-total expenditure by the central government,trg-total revenue and grants of

${ }^{4}$ Elect - a dummy variable with the value 1 in the election year and 0 otherwise.

${ }^{5}$ For the definitions of these tests see Table 2 .

* - Significant at the 10 percent level; ** - Significant at the 5 percent level; *** - Significant at the 1 percent level. 
Table 5: Predetermined vs. Endogenous Election Dates.

\begin{tabular}{|c|c|c|c|c|c|c|c|c|c|c|c|c|}
\hline \multirow{4}{*}{$\begin{array}{l}\text { Estimation period } \\
\text { Dependent variable }\end{array}$} & \multicolumn{3}{|c|}{$\begin{array}{c}\text { All Democracies, FE } \\
\text { Estimation }\end{array}$} & \multicolumn{3}{|c|}{$\begin{array}{c}\text { "New Democracies", FE } \\
\text { Estimation }\end{array}$} & \multicolumn{3}{|c|}{$\begin{array}{c}\text { "New Democracies", GMM }{ }^{1} \\
\text { Estimation }\end{array}$} & \multicolumn{3}{|c|}{$\begin{array}{l}\text { Old Democracies, FE } \\
\text { Estimation }\end{array}$} \\
\hline & \multicolumn{3}{|c|}{$(1)$} & \multicolumn{3}{|c|}{$(2)$} & \multicolumn{3}{|c|}{ (3) } & \multicolumn{3}{|c|}{$(4)$} \\
\hline & & $960-200$ & & & 1960-2001 & & & $1960-2001$ & & & $960-200$ & \\
\hline & balance & texp & $\operatorname{trg}$ & balance & texp & $\operatorname{trg}$ & balance & texp & $\operatorname{trg}$ & balance & texp & $\operatorname{trg}$ \\
\hline Elect-pred $^{3}$ & $\begin{array}{l}-0.294^{*} \\
(0.150)\end{array}$ & $\begin{array}{l}-0.010 \\
(0.235)\end{array}$ & $\begin{array}{l}-0.308 \\
(0.208)\end{array}$ & $\begin{array}{c}-0.840^{* * *} \\
(0.325)\end{array}$ & $\begin{array}{c}0.407 \\
(0.344)\end{array}$ & $\begin{array}{l}-0.429 \\
(0.279)\end{array}$ & $\begin{array}{l}-0.650^{* *} \\
(0.302)\end{array}$ & $\begin{array}{c}0.487 \\
(0.356)\end{array}$ & $\begin{array}{c}0.028 \\
(0.438)\end{array}$ & $\begin{array}{l}-0.062 \\
(0.164)\end{array}$ & $\begin{array}{l}-0.224 \\
(0.176)\end{array}$ & $\begin{array}{r}-0.285^{* *} \\
(0.143)\end{array}$ \\
\hline Elect-endog 4 & $\begin{array}{c}-0.417^{* *} \\
(0.185)\end{array}$ & $\begin{array}{c}0.204 \\
(0.293)\end{array}$ & $\begin{array}{l}-0.190 \\
(0.259)\end{array}$ & $\begin{array}{l}-0.930^{* *} \\
(0.467)\end{array}$ & $\begin{array}{l}1.492^{\star * *} \\
(0.501)\end{array}$ & $\begin{array}{c}0.419 \\
(0.401)\end{array}$ & $\begin{array}{l}-0.894^{*} \\
(0.483)\end{array}$ & $\begin{array}{l}1.764^{* * *} \\
(0.578)\end{array}$ & $\begin{array}{c}0.738 \\
(0.570)\end{array}$ & $\begin{array}{l}-0.138 \\
(0.198)\end{array}$ & $\begin{array}{l}-0.043 \\
(0.214)\end{array}$ & $\begin{array}{l}-0.166 \\
(0.175)\end{array}$ \\
\hline Adjusted $\mathrm{R}^{2}$ & 0.686 & 0.906 & 0.915 & 0.460 & 0.938 & 0.954 & $\ldots$ & $\ldots$ & $\ldots$ & 0.768 & 0.961 & 0.970 \\
\hline F- Statistic & 48.13 & 210.65 & 237.54 & 9.22 & 148.82 & 201.03 & $\ldots$ & $\ldots$ & $\ldots$ & 94.73 & 696.26 & 920.06 \\
\hline DW Statistic & 1.943 & 1.548 & 1.448 & 1.822 & 2.035 & 2.103 & $\ldots$ & $\ldots$ & $\ldots$ & 1.894 & 1.966 & 1.861 \\
\hline Sargan test ${ }^{5}$ & $\ldots$ & $\ldots$ & $\ldots$ & $\ldots$ & $\ldots$ & $\ldots$ & 1.000 & 1.000 & 1.000 & $\ldots$ & $\ldots$ & $\ldots$ \\
\hline $2^{\text {nd }}$ Order Test ${ }^{5}$ & $\ldots$ & $\ldots$ & $\ldots$ & $\cdots$ & $\ldots$ & $\ldots$ & 0.650 & 0.857 & 0.382 & $\cdots$ & $\ldots$ & $\ldots$ \\
\hline No. of countries & 68 & 68 & 68 & 36 & 36 & 36 & 36 & 36 & 36 & 32 & 32 & 32 \\
\hline No. of obs. & 1617 & 1632 & 1641 & 416 & 424 & 416 & 339 & 347 & 339 & 1105 & 1112 & 1128 \\
\hline Avg. time series length & 23.8 & 24.0 & 24.1 & 11.6 & 11.8 & 11.6 & 9.4 & 9.6 & 9.4 & 34.5 & 34.8 & 35.3 \\
\hline
\end{tabular}

${ }^{1}$ Estimated using the Arellano-Bond procedure as described in table 1.

${ }^{2}$ Variable definitions (all in percent of GDP):balance-central government surplus,texp-total expenditure by the central governmenttrg-total revenue and grants of th $\epsilon$ ${ }^{3}$ Elect-pred - a dummy variable with the value 1 in an election year if the elections are in their predetermined dates, as defined in the text, and 0 otherwise.

${ }^{4}$ Elect-endog - a dummy variable with the value 1 in an election year if the elections are not in their predetermined dates, as defined in the text, and 0 otherwise.

${ }^{5}$ For the definitions of these tests see Table 2.

* - Significant at the 10 percent level; ** - Significant at the 5 percent level; ${ }^{* * *}$ - Significant at the 1 percent level. 
Table 6: Constitutional Rules and the Political Budget Cyclt

\begin{tabular}{|c|c|c|c|c|c|c|c|c|c|c|c|c|}
\hline \multirow{4}{*}{$\begin{array}{l}\text { Estimation period } \\
\text { Dependent variable }\end{array}$} & \multicolumn{3}{|c|}{$\begin{array}{c}\text { All Democracies, } \mathrm{FE} \\
\text { Estimation }\end{array}$} & \multicolumn{3}{|c|}{$\begin{array}{c}\text { "New Democracies", FE } \\
\text { Estimation }\end{array}$} & \multicolumn{3}{|c|}{$\begin{array}{c}\text { "New Democracies", GMM" } \\
\text { Estimation }\end{array}$} & \multicolumn{3}{|c|}{$\begin{array}{l}\text { Old Democracies, FE } \\
\text { Estimation }\end{array}$} \\
\hline & \multirow{2}{*}{\multicolumn{3}{|c|}{$\begin{array}{c}(1) \\
1960-2001\end{array}$}} & \multicolumn{3}{|c|}{$(2)$} & \multirow{2}{*}{\multicolumn{3}{|c|}{$\frac{(3)}{1960-2001}$}} & \multirow{2}{*}{\multicolumn{3}{|c|}{$\frac{(4)}{1960-2001}$}} \\
\hline & & & & & $960-200$ & & & & & & & \\
\hline & balance & texp & $\operatorname{trg}$ & balance & texp & $\operatorname{trg}$ & balance & texp & $\operatorname{trg}$ & balance & texp & $\operatorname{trg}$ \\
\hline Elect-pres $^{3}$ & $\begin{array}{l}-0.395^{*} \\
(0.218)\end{array}$ & $\begin{array}{c}0.386 \\
(0.343)\end{array}$ & $\begin{array}{l}0.050 \\
(0.301)\end{array}$ & $\begin{array}{c}-0.850^{\star * *} \\
(0.328)\end{array}$ & $\begin{array}{l}0.755^{\star *} \\
(0.354)\end{array}$ & $\begin{array}{l}-0.098 \\
(0.283)\end{array}$ & $\begin{array}{l}-0.684^{* *} \\
(0.324)\end{array}$ & $\begin{array}{l}0.942^{* *} \\
(0.376)\end{array}$ & $\begin{array}{c}0.374 \\
(0.447)\end{array}$ & $\begin{array}{c}0.172 \\
(0.315)\end{array}$ & $\begin{array}{l}-0.206 \\
(0.339)\end{array}$ & $\begin{array}{c}0.074 \\
(0.271)\end{array}$ \\
\hline Elect-parl $^{4}$ & $\begin{array}{c}-0.317^{\star *} \\
(0.147)\end{array}$ & $\begin{array}{l}-0.070 \\
(0.231)\end{array}$ & $\begin{array}{c}-0.407^{* *} \\
(0.205)\end{array}$ & $\begin{array}{l}-0.907^{*} \\
(0.482)\end{array}$ & $\begin{array}{c}0.724 \\
(0.500)\end{array}$ & $\begin{array}{l}-0.293 \\
(0.415)\end{array}$ & $\begin{array}{l}-0.877^{*} \\
(0.501)\end{array}$ & $\begin{array}{l}1.058^{*} \\
(0.642)\end{array}$ & $\begin{array}{c}0.109 \\
(0.601)\end{array}$ & $\begin{array}{l}-0.148 \\
(0.146)\end{array}$ & $\begin{array}{l}-0.141 \\
(0.158)\end{array}$ & $\begin{array}{r}-0.309^{* *} \\
(0.129)\end{array}$ \\
\hline Adjusted $\mathrm{R}^{2}$ & 0.686 & 0.906 & 0.915 & 0.460 & 0.937 & 0.954 & $\ldots$ & $\ldots$ & $\ldots$ & 0.768 & 0.961 & 0.970 \\
\hline F-Statistic & 48.12 & 210.78 & 237.78 & 9.22 & 147.44 & 199.34 & $\ldots$ & $\ldots$ & $\ldots$ & 94.81 & 695.95 & 921.22 \\
\hline DW Statistic & 1.943 & 1.548 & 1.449 & 1.822 & 2.046 & 2.109 & $\ldots$ & $\ldots$ & $\ldots$ & 1.897 & 1.965 & 1.863 \\
\hline Sargan test ${ }^{5}$ & $\ldots$ & $\ldots$ & $\ldots$ & $\ldots$ & $\ldots$ & $\ldots$ & 1.000 & 1.000 & 1.000 & $\ldots$ & $\ldots$ & $\ldots$ \\
\hline $2^{\text {nd }}$ Order Test ${ }^{5}$ & $\ldots$ & $\ldots$ & $\ldots$ & $\ldots$ & $\ldots$ & $\ldots$ & 0.769 & 0.847 & 0.342 & $\ldots$ & $\ldots$ & $\ldots$ \\
\hline No. of countries & 68 & 68 & 68 & 36 & 36 & 36 & 36 & 36 & 36 & 32 & 32 & 32 \\
\hline No. of obs. & 1617 & 1632 & 1641 & 416 & 424 & 416 & 339 & 347 & 339 & 1105 & 1112 & 1128 \\
\hline Avg. time series lengtr & 23.8 & 24.0 & 24.1 & 11.6 & 11.8 & 11.6 & 9.4 & 9.6 & 9.4 & 34.5 & 34.8 & 35.3 \\
\hline
\end{tabular}

The covariates are as in table 1.

${ }^{1}$ Estimated using the Arellano-Bond procedure as described in table 1.

${ }^{2}$ Variable definitions (all in percent of GDP):balance-central government surplus,texp-total expenditure by the central governmenttrg-total revenue and grants of

${ }^{3}$ Elect-pres - a dummy variable with the value 1 in an election year if system is presidential, and 0 otherwise.

${ }^{4}$ Elect-parl - a dummy variable with the value 1 in an election year if system is parlamentary, and 0 otherwise.

${ }^{5}$ For the definitions of these tests see Table 2.

* - Significant at the 10 percent level; ** - Significant at the 5 percent level; *** - Significant at the 1 percent level. 
Table 7: Electoral Rules and the Political Budget Cycl€

\begin{tabular}{|c|c|c|c|c|c|c|c|c|c|c|c|c|}
\hline \multirow{4}{*}{$\begin{array}{l}\text { Estimation period } \\
\text { Dependent variable }\end{array}$} & \multicolumn{3}{|c|}{$\begin{array}{c}\text { All Democracies, FE } \\
\text { Estimation }\end{array}$} & \multicolumn{3}{|c|}{$\begin{array}{c}\text { "New Democracies", FE } \\
\text { Estimation }\end{array}$} & \multicolumn{3}{|c|}{$\begin{array}{c}\text { "New Democracies", GMM"1 } \\
\text { Estimation }\end{array}$} & \multicolumn{3}{|c|}{$\begin{array}{l}\text { Old Democracies, FE } \\
\text { Estimation }\end{array}$} \\
\hline & \multicolumn{3}{|c|}{$(1)$} & \multicolumn{3}{|c|}{$(2)$} & \multicolumn{3}{|c|}{ (3) } & \multicolumn{3}{|c|}{ (4) } \\
\hline & \multicolumn{3}{|c|}{$1960-2001$} & \multicolumn{3}{|c|}{$1960-2001$} & \multicolumn{3}{|c|}{$1960-2001$} & \multicolumn{3}{|c|}{$1960-2001$} \\
\hline & balance & texp & $\operatorname{trg}$ & balance & texp & $\operatorname{trg}$ & balance & texp & $\operatorname{trg}$ & balance & texp & $\operatorname{trg}$ \\
\hline Elect-prop ${ }^{3}$ & $\begin{array}{l}-0.339^{* *} \\
(0.140)\end{array}$ & $\begin{array}{c}0.093 \\
(0.220)\end{array}$ & $\begin{array}{l}-0.221 \\
(0.195)\end{array}$ & $\begin{array}{c}-0.995^{\star * *} \\
(0.305)\end{array}$ & $\begin{array}{c}0.908^{\star * *} \\
(0.325)\end{array}$ & $\begin{array}{l}-0.036 \\
(0.263)\end{array}$ & $\begin{array}{c}-0.840^{* * *} \\
(0.283)\end{array}$ & $\begin{array}{l}1.168^{* * *} \\
(0.383)\end{array}$ & $\begin{array}{c}0.475 \\
(0.424)\end{array}$ & $\begin{array}{l}-0.067 \\
(0.153)\end{array}$ & $\begin{array}{l}-0.148 \\
(0.165)\end{array}$ & $\begin{array}{l}-0.200 \\
(0.135)\end{array}$ \\
\hline Elect-maj $^{4}$ & $\begin{array}{l}-0.340 \\
(0.254)\end{array}$ & $\begin{array}{l}-0.003 \\
(0.400)\end{array}$ & $\begin{array}{l}-0.401 \\
(0.349)\end{array}$ & $\begin{array}{l}-0.356 \\
(0.613)\end{array}$ & $\begin{array}{c}0.074 \\
(0.658)\end{array}$ & $\begin{array}{l}-0.652 \\
(0.528)\end{array}$ & $\begin{array}{l}-0.332 \\
(0.609)\end{array}$ & $\begin{array}{c}0.207 \\
(0.677)\end{array}$ & $\begin{array}{l}-0.766 \\
(0.664)\end{array}$ & $\begin{array}{l}-0.168 \\
0.264\end{array}$ & $\begin{array}{l}-0.167 \\
(0.285)\end{array}$ & $\begin{array}{l}-0.355 \\
(0.229)\end{array}$ \\
\hline Adjusted $\mathrm{R}^{2}$ & 0.686 & 0.906 & 0.915 & 0.461 & 0.937 & 0.954 & $\ldots$ & $\cdots$ & $\cdots$ & 0.768 & 0.961 & 0.970 \\
\hline F-Statistic & 48.11 & 210.60 & 237.55 & 9.258 & 147.97 & 199.86 & $\ldots$ & $\ldots$ & $\ldots$ & 94.73 & 695.94 & 920.09 \\
\hline DW Statistic & 1.943 & 1.548 & 1.447 & 1.819 & 2.040 & 2.105 & $\ldots$ & $\ldots$ & $\ldots$ & 1.894 & 1.965 & 1.860 \\
\hline Sargan test ${ }^{5}$ & $\cdots$ & $\ldots$ & $\ldots$ & $\ldots$ & $\ldots$ & $\ldots$ & 1.000 & 1.000 & 1.000 & $\cdots$ & $\ldots$ & $\ldots$ \\
\hline $2^{\text {nd }}$ Order Test ${ }^{5}$ & $\ldots$ & $\ldots$ & $\ldots$ & $\ldots$ & $\ldots$ & $\ldots$ & 0.791 & 0.917 & 0.467 & $\ldots$ & $\ldots$ & $\ldots$ \\
\hline No. of countries & 68 & 68 & 68 & 36 & 36 & 36 & 36 & 36 & 36 & 32 & 32 & 32 \\
\hline No. of obs. & 1617 & 1632 & 1641 & 416 & 424 & 416 & 339 & 347 & 339 & 1105 & 1112 & 1128 \\
\hline Avg. time series lengtr & 23.8 & 24.0 & 24.1 & 11.6 & 11.8 & 11.6 & 9.4 & 9.6 & 9.4 & 34.5 & 34.8 & 35.3 \\
\hline
\end{tabular}

The covariates are as in table 1.

${ }^{1}$ Estimated using the Arellano-Bond procedure as described in table 1.

${ }^{2}$ Variable definitions (all in percent of GDP):balance-central government surplus,texp-total expenditure by the central governmenttrg-total revenue and grants of

${ }^{3}$ Elect-prop - a dummy variable with the value 1 in an election year if the electoral system is proportional, and 0 otherwise.

${ }^{4}$ Elect-maj - a dummy variable with the value 1 in an election year if the electoral system is majoritarian, and 0 otherwise.

${ }^{5}$ For the definitions of these tests see Table 2.

* - Significant at the 10 percent level; ** - Significant at the 5 percent level; *** - Significant at the 1 percent level. 
Table 8: The Effect of the Level of Democracy on the Political Budget Cycle.

\begin{tabular}{|c|c|c|c|c|c|c|c|c|c|c|c|c|}
\hline \multirow{3}{*}{$\begin{array}{l}\text { Estimation period } \\
\text { Dependent variable }^{2}\end{array}$} & \multicolumn{3}{|c|}{$\begin{array}{l}\text { All Democracies, FE } \\
\text { Estimation }\end{array}$} & \multicolumn{3}{|c|}{$\begin{array}{c}\text { "New Democracies", FE } \\
\text { Estimation }\end{array}$} & \multicolumn{3}{|c|}{$\begin{array}{l}\text { "New Democracies", GMM }{ }^{1} \\
\text { Estimation }\end{array}$} & \multicolumn{3}{|c|}{$\begin{array}{l}\text { Old Democracies, FE } \\
\text { Estimation }\end{array}$} \\
\hline & \multicolumn{3}{|c|}{$\frac{(1)}{1960-2001}$} & \multicolumn{3}{|c|}{$\frac{(2)}{1960-2001}$} & \multicolumn{3}{|c|}{$\frac{(3)}{1960-2001}$} & \multicolumn{3}{|c|}{$\frac{(4)}{1960-2001}$} \\
\hline & balance & texp & $\operatorname{trg}$ & balance & texp & $\operatorname{trg}$ & balance & texp & $\operatorname{trg}$ & balance & texp & $\operatorname{trg}$ \\
\hline Elect-low ${ }^{3}$ & $\begin{array}{c}-0.634^{* * *} \\
(0.193)\end{array}$ & $\begin{array}{c}0.364 \\
(0.303)\end{array}$ & $\begin{array}{l}-0.230 \\
(0.266)\end{array}$ & $\begin{array}{c}-0.783^{* * *} \\
(0.300)\end{array}$ & $\begin{array}{l}0.607^{*} \\
(0.319)\end{array}$ & $\begin{array}{l}-0.265 \\
(0.258)\end{array}$ & $\begin{array}{c}-0.736^{* *} \\
(0.311)\end{array}$ & $\begin{array}{l}0.855^{* *} \\
(0.354)\end{array}$ & $\begin{array}{c}0.198 \\
(0.424)\end{array}$ & $\begin{array}{l}-0.255 \\
(0.273)\end{array}$ & $\begin{array}{l}-0.196 \\
(0.294)\end{array}$ & $\begin{array}{l}-0.353 \\
(0.232)\end{array}$ \\
\hline Elect-high $^{4}$ & $\begin{array}{l}-0.150 \\
(0.157)\end{array}$ & $\begin{array}{l}-0.122 \\
(0.247)\end{array}$ & $\begin{array}{l}-0.286 \\
(0.220)\end{array}$ & $\begin{array}{c}-1.264^{* *} \\
(0.636)\end{array}$ & $\begin{array}{l}1.401^{* *} \\
(0.686)\end{array}$ & $\begin{array}{c}-(0.336) \\
(0.548)\end{array}$ & $\begin{array}{l}-0.735 \\
(0.554)\end{array}$ & $\begin{array}{l}1.394^{*} \\
(0.756)\end{array}$ & $\begin{array}{c}0.721 \\
(0.751)\end{array}$ & $\begin{array}{c}-0.042 \\
(0.152)\end{array}$ & $\begin{array}{l}-0.139 \\
(0.163)\end{array}$ & $\begin{array}{l}-0.201 \\
(0.134)\end{array}$ \\
\hline Adjusted $\mathbf{R}^{2}$ & 0.687 & 0.906 & 0.915 & 0.461 & 0.937 & 0.954 & $\ldots$ & $\ldots$ & $\ldots$ & 0.768 & 0.961 & 0.970 \\
\hline F- Statistic & 48.28 & 210.83 & 237.52 & 9.24 & 147.90 & 199.81 & $\ldots$ & $\ldots$ & $\ldots$ & 94.77 & 695.95 & 920.07 \\
\hline DW Statistic & 1.942 & 1.549 & 1.448 & 1.826 & 2.043 & 2.103 & $\ldots$ & $\ldots$ & $\ldots$ & 1.893 & 1.965 & 1.860 \\
\hline Sargan test ${ }^{5}$ & $\ldots$ & $\ldots$ & $\ldots$ & $\ldots$ & $\ldots$ & $\ldots$ & 1.000 & 1.000 & 1.000 & $\ldots$ & $\ldots$ & $\ldots$ \\
\hline $2^{\text {nd }}$ Order Test ${ }^{5}$ & $\ldots$ & $\ldots$ & $\ldots$ & $\ldots$ & $\ldots$ & $\ldots$ & 0.705 & 0.943 & 0.324 & $\ldots$ & $\ldots$ & $\ldots$ \\
\hline No. of countries & 68 & 68 & 68 & 36 & 36 & 36 & 36 & 36 & 36 & 32 & 32 & 32 \\
\hline No. of obs. & 1617 & 1632 & 1641 & 416 & 424 & 416 & 339 & 347 & 339 & 1105 & 1112 & 1128 \\
\hline Avg. time series lengt| & 23.8 & 24.0 & 24.1 & 11.6 & 11.8 & 11.6 & 9.4 & 9.6 & 9.4 & 34.5 & 34.8 & 35.3 \\
\hline
\end{tabular}

The covariates are as in table 1.

${ }^{1}$ Estimated using the Arellano-Bond procedure as described in table 1.

${ }^{2}$ Variable definitions (all in percent of GDP): balance-central government surplus; texp-total expenditure by the central government; trg-total revenue and

${ }^{3}$ Elect-low - a dummy variable with the value 1 in an election year if the level of democracy is between 0 and 9 , and 0 otherwise.

${ }^{4}$ Elect-high - a dummy variable with the value 1 if the level of democracy is 10 , and 0 otherwise.

${ }^{5}$ For the definitions of these tests see Table 2.

* - Significant at the 10 percent level; ** - Significant at the 5 percent level; *** - Significant at the 1 percent level. 
Table 9: Alternative Timing of the Budget Cycle.

\begin{tabular}{|c|c|c|c|}
\hline \multirow{3}{*}{$\begin{array}{l}\text { Estimation period } \\
\text { Dependent variable }\end{array}$} & \multicolumn{3}{|c|}{ Balance $^{1}$, FE Estimation } \\
\hline & \multicolumn{3}{|c|}{$\frac{(2)}{1960-2001}$} \\
\hline & All Democracies & New Democracies & Old Democracies \\
\hline Elect-half1 ${ }^{2}$ & $\begin{array}{l}-0.150 \\
(0.164)\end{array}$ & $\begin{array}{l}-0.448 \\
(0.386)\end{array}$ & $\begin{array}{l}0.058 \\
(0.177)\end{array}$ \\
\hline${\text { Elect-half } 2^{3}}^{3}$ & $\begin{array}{c}-0.537^{* * *} \\
(0.166)\end{array}$ & $\begin{array}{c}-1.233^{* * *} \\
(0.362)\end{array}$ & $\begin{array}{l}-0.252 \\
(0.181)\end{array}$ \\
\hline Adjusted $\mathrm{R}^{2}$ & 0.687 & 0.463 & 0.768 \\
\hline F- Statistic & 48.249 & 9.329 & 94.909 \\
\hline DW Statistic & 1.944 & 1.814 & 1.896 \\
\hline No. of countries & 68 & 36 & 32 \\
\hline No. of obs. & 1617 & 416 & 1105 \\
\hline Avg. time series length & 23.8 & 11.6 & 34.5 \\
\hline
\end{tabular}

${ }^{1}$ Variable definitions (in percent of GDP): balance-central government surplus.

${ }^{2}$ Elect-half1 - a dummy variable with the value 1 in an election year if the elections are in the first half of the year, and 0 otherwise.

${ }^{3}$ Elect-half2 - a dummy variable with the value 1 in an election year if the elections are in the second half of the year, and 0 otherwise.

* - Significant at the 10 percent level; ** - Significant at the 5 percent level; *** - Significant at the 1 percent level. 
Table A1: Sample Characteristics and data adjustments

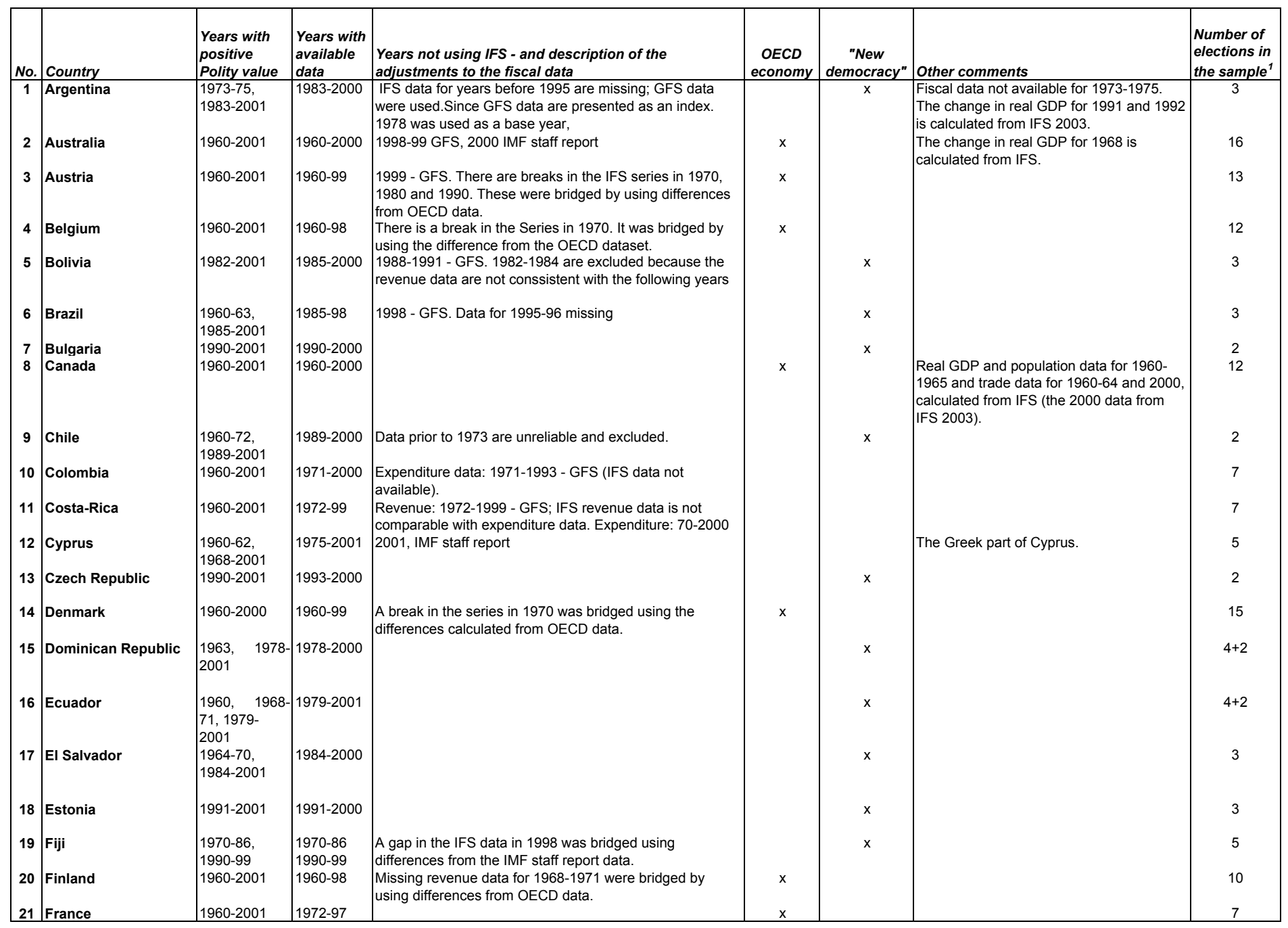




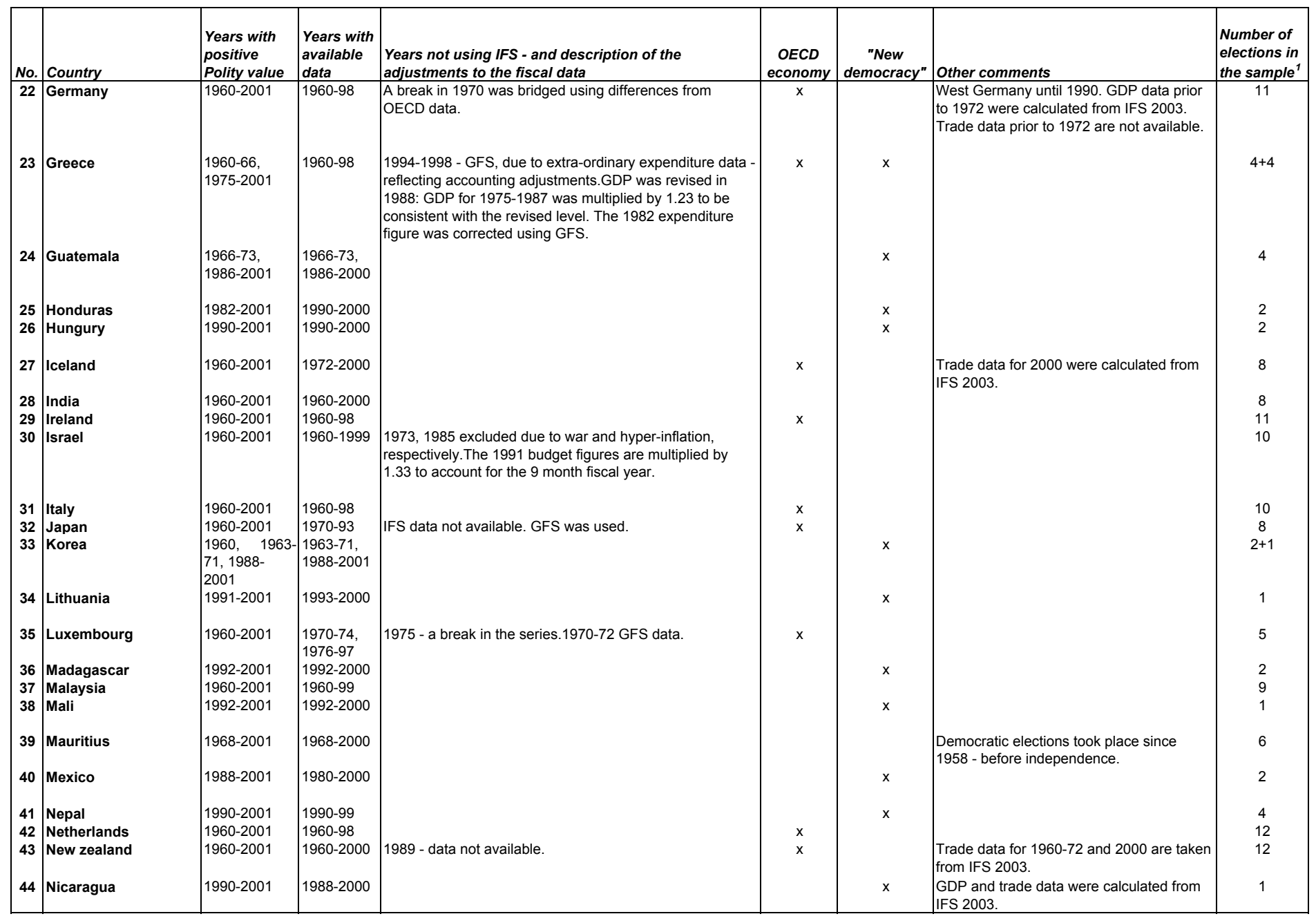




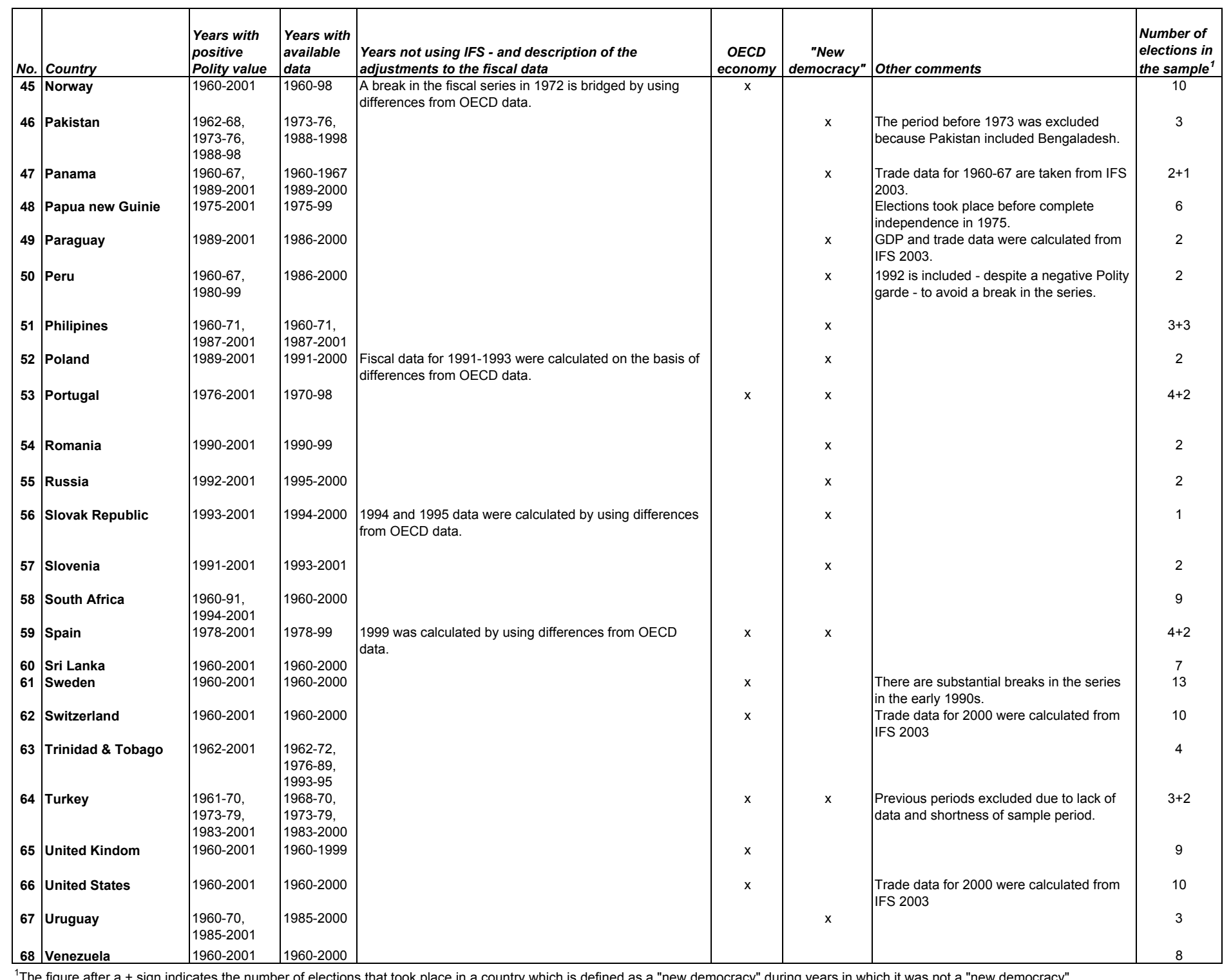

'The figure after a + sign indicates the number of elections that took place in a country which is defined as a "new democracy" during years in which it was not a "new democracy". 
Table A2: The "New Democracies"

\begin{tabular}{|c|c|c|c|c|}
\hline No. & Country & $\begin{array}{c}\text { Year of Becoming a } \\
\text { Democracy }^{1}\end{array}$ & $\begin{array}{c}\text { Elections Included as a "New } \\
\text { Democracy" }\end{array}$ & $\begin{array}{l}\text { "Transition" } \\
\text { Economy }\end{array}$ \\
\hline 1 & Argentina & 1983 & $89,95,99$ & \\
\hline 2 & Bolivia & 1982 & $89,93,97$ & \\
\hline 3 & Brazil & 1985 & $89,94,98$ & \\
\hline 4 & Bulgaria & 1990 & 92,96 & $\mathrm{x}$ \\
\hline 5 & Chile & 1989 & 93,00 & $\mathrm{x}$ \\
\hline 6 & Czech Republic & 1990 & 96,98 & \\
\hline 7 & Dominican Republic & 1978 & $82,86,90,94$ & \\
\hline 8 & Ecuador & 1979 & $84,88,92,96$ & \\
\hline 9 & El Salvador & 1984 & $89,94,99$ & \\
\hline 10 & Estonia & 1991 & $92,95,99$ & $\mathrm{x}$ \\
\hline 11 & Fiji & 1970,1990 & $73,77,82,92,99$ & \\
\hline 12 & Greece & 1975 & $77,81,85,89$ & \\
\hline 13 & Guatemala & 1966, 1986 & $70,90,95,99$ & \\
\hline 14 & Honduras & 1982 & $85^{2}, 89^{2}, 93,97$ & \\
\hline 15 & Hungary & 1990 & 94,98 & $\mathrm{x}$ \\
\hline 16 & Korea & 1988 & 92,97 & \\
\hline 17 & Lithuania & 1991 & 97 & $x$ \\
\hline 18 & Madagascar & 1992 & 93,96 & \\
\hline 19 & Mali & 1992 & 97 & \\
\hline 20 & Mexico & 1988 & 94,00 & \\
\hline 21 & Nepal & 1990 & $91,95,97,99$ & \\
\hline 22 & Nicaragua & 1990 & 96 & \\
\hline 23 & Pakistan & 1988 & $91,94,97$ & \\
\hline 24 & Panama & 1989 & 94,99 & \\
\hline 25 & Paraguay & 1989 & 93,98 & \\
\hline 26 & Peru & 1980 & 90,95 & \\
\hline 27 & Philipines & 1987 & $92,95,98$ & \\
\hline 28 & Poland & 1989 & 95,00 & $x$ \\
\hline 29 & Portugal & 1976 & $80,83,85,87$ & \\
\hline 30 & Romania & 1990 & 92,96 & $\mathrm{x}$ \\
\hline 31 & Russia & 1992 & 96,00 & $\mathrm{x}$ \\
\hline 32 & Slovak Republic & 1993 & 98 & $\mathrm{x}$ \\
\hline 33 & Slovenia & 1991 & 96,00 & $x$ \\
\hline 34 & Spain & 1978 & $79,82,86,89$ & \\
\hline 35 & Turkey & 1983 & $87,91,95$ & \\
\hline 36 & Uruguay & 1985 & $89,94,99$ & \\
\hline
\end{tabular}

${ }^{1}$ The first year in which the country receives a positive value in the POLITY scale, following a substantial period of negative values. The actual transition (e.g., first democratic elections) can take place during the previous year.

${ }^{2}$ Expenditure only.

Source: Calculations based on the POLITY IV dataset, produced by the University of Maryland, and the World Bank Database on Political Institutions. 
Table A3: Countries excluded from the sample ${ }^{1}$

\begin{tabular}{|c|c|c|c|}
\hline No. & Country & \begin{tabular}{|l} 
Years With \\
Positive Polity
\end{tabular} & Reason for exclusion \\
\hline 1 & Bahamas, The & no polity & No POLITY rank \\
\hline 2 & Bangladesh & $72-73,91-2001$ & No fiscal data in IFS. \\
\hline 3 & Barbados & no polity & No POLITY rank \\
\hline 4 & Belarus & 1991-1995 & Available sample too short. \\
\hline 5 & Belize & no polity & No POLITY rank \\
\hline 6 & Bostwana & $1966-2001$ & Extra-ordinary changes in the series. \\
\hline 7 & Burkina Faso & $78-79$ & Only two years with positive POLITY rank \\
\hline 8 & Burundi & all negative & Negative POLITY rank throuout the sample period. \\
\hline 9 & Cameroon & all negative & Negative POLITY rank throuout the sample period. \\
\hline 10 & Chad & all negative & Negative POLITY rank throuout the sample period. \\
\hline 11 & Congo & $60-62,92-96$ & Sample too short \\
\hline 12 & Croatia & 2000 & Sample too short \\
\hline 13 & Egypt, Arab Rep. & all negative & Negative POLITY rank throuout the sample period. \\
\hline 14 & Gambia, The & $65-93$ & No fiscal data in IFS. \\
\hline 15 & Ghana & $70-71,79-80,96-2001$ & No fiscal data in IFS. \\
\hline 16 & Guyana & 1966-79, 1992-2001 & Available periods too short, due to low quality data. \\
\hline 17 & Indonesia & $1999-2001$ & Sample too short \\
\hline 18 & Iran & $1997-2001$ & Sample too short \\
\hline 19 & Jamaica & $1960-2001$ & No fiscal data in IFS. \\
\hline 20 & Kenya & 1963-1968 & Sample too short \\
\hline 21 & Latvia & $1991-2001$ & Sample too short \\
\hline 22 & Liberia & $1997-2001$ & Sample too short \\
\hline 23 & Malawi & 1994-2001 & Sample with IFS data too short \\
\hline 24 & Maldives & no polity & No POLITY rank \\
\hline 25 & Malta & no polity & No POLITY rank \\
\hline 26 & Nigeria & $60-65,79-83,99-2001$ & Each democratic episode is too short. \\
\hline 27 & Senegal & $2000-2001$ & Sample too short \\
\hline 28 & Siera Leone & $61-66,68-70,97$ & Each democratic episode is too short. \\
\hline 29 & Singapore & $1960-1962$ & Sample too short \\
\hline 30 & Solomon Islands & no polity & No POLITY rank \\
\hline 31 & St.Lucia & no polity & No POLITY rank \\
\hline 32 & Suriname & no polity & No POLITY rank \\
\hline 33 & Syrian, Arab Rep & all negative & Negative POLITY rank throuout the sample period. \\
\hline 34 & Thialand & $\begin{array}{l}69-70,74-75,78- \\
90,92-2001\end{array}$ & Too many breaks in the periods of democracy. \\
\hline 35 & Togo & all negative & Negative POLITY rank throuout the sample period. \\
\hline 36 & Tunisia & all negative & Negative POLITY rank throuout the sample period. \\
\hline 37 & Zambia & $64-71,91-2001$ & Extra-ordinary changes in the series. \\
\hline 38 & Zimbabwe & $70-78,80-86$ & Available periods too short. \\
\hline
\end{tabular}

${ }^{1}$ Countries that appear in the IFS or that were used in other studies. 
Table A4: Election Years According to Various Classifications

\begin{tabular}{|c|c|c|c|}
\hline & All Democracies & New Democracies & Old Democracies \\
\hline Elections ${ }^{1}$ & 413 & 94 & 300 \\
\hline \multicolumn{4}{|l|}{ Of which: } \\
\hline Developed countries & 239 & 15 & 214 \\
\hline Less developed countries & 174 & 79 & 86 \\
\hline $\begin{array}{l}\text { Of which: } \\
\text { Transition countries }\end{array}$ & 19 & 19 & 0 \\
\hline Predetermined elections & 252 & 63 & 180 \\
\hline Endogeneous elections & 161 & 31 & 120 \\
\hline Elections in Presidential systems & 122 & 63 & 49 \\
\hline Elections in Parliamentary systems & 291 & 31 & 251 \\
\hline Proportional elections $^{2}$ & 318 & 75 & 229 \\
\hline Majoritarian elections ${ }^{2}$ & 91 & 19 & 71 \\
\hline High level of democracy & 257 & 17 & 234 \\
\hline Low level of democracy & 156 & 77 & 66 \\
\hline
\end{tabular}

${ }^{1}$ The number of election years in "new" and "old" democracies does not add-up to the total number of election years because elections that took place in "new" democracies after the fourth elections are excluded from both samples but are included in the "all democracies" sample.

${ }^{2}$ The number of proportional and majoritarian elections does not add-up to the total number of elections because the elections in Panama in 1964 and in the Philipines in 1961, 1967 and 1969 were not classifies as either in the DPI. 